\title{
norden
}

\section{Riskbedömning av partnervåld}

Erfarenheter och utmaningar i de nordiska länderna

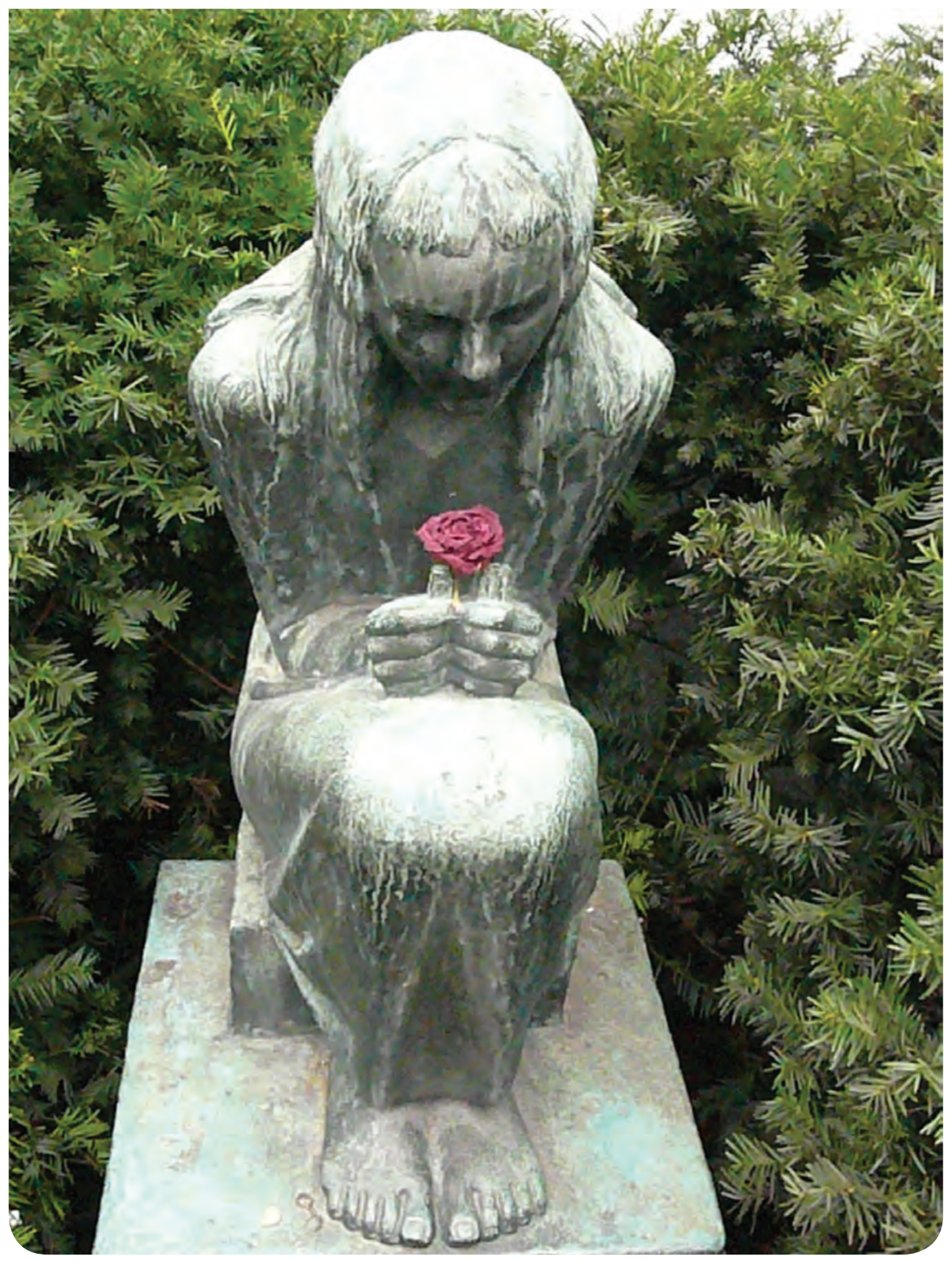



4 norden 



\section{Riskbedömning av partnervåld}

Erfarenheter och utmaningar i de nordiska länderna

Nordling Barbro

TemaNord 2014:521 
Riskbedömning av partnervåld

Erfarenheter och utmaningar i de nordiska länderna

Nordling Barbro

ISBN 978-92-893-2753-4

ISBN 978-92-893-2754-1 (EPUB)

http://dx.doi.org/10.6027/TN2014-521

TemaNord 2014:521

ISSN 0908-6692

(C) Nordiska ministerrådet 2014

Layout: Hanne Lebech

Omslagsfoto: Freja Ulvestad Kärki

Tryck: Rosendahls-Schultz Grafisk

Upplaga: 266

Printed in Denmark

Denna rapport är utgiven med finansiellt stöd från Nordiska ministerrådet. Innehållet i rapporten avspeglar inte nödvändigtvis Nordiska ministerrådets synpunkter, åsikter eller rekommendationer.

www.norden.org/sv/publikationer

\section{Det nordiska samarbetet}

Det nordiska samarbetet är ett av världens mest omfattande regionala samarbeten. Det omfattar Danmark, Finland, Island, Norge och Sverige samt Färöarna, Grönland och Åland.

Det nordiska samarbetet är politiskt, ekonomiskt och kulturellt förankrat och är en viktig partner i europeiskt och internationellt samarbete. Den nordiska gemenskapen arbetar för ett starkt Norden i ett starkt Europa.

Det nordiska samarbetet ska stärka nordiska och regionala intressen och värderingar i en global omvärld. Gemensamma värderingar länderna emellan bidrar till att stärka Nordens ställning som en av världens mest innovativa och konkurrenskraftiga regioner.

Nordiska ministerrådet

Ved Stranden 18

DK-1061 København K

Telefon (+45) 33960200

www.norden.org 


\section{Innehåll}

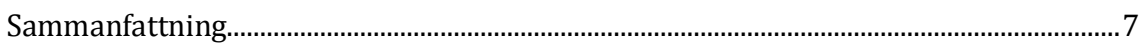

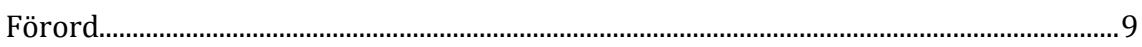

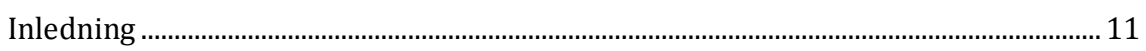

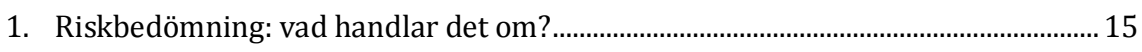

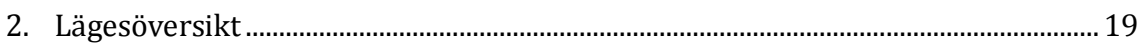

3. Styrkor respektive utmaningar vid användningen av MARAK respektive

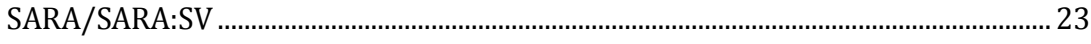

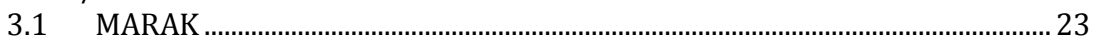

3.2 SARA, SARA:SV ........................................................................................... 27

4. Avslutande reflektioner................................................................................................... 33

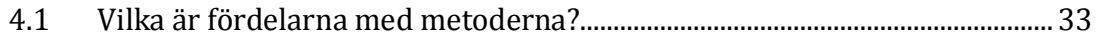

4.2 Vilka utmaningar har man mött?....................................................................... 34

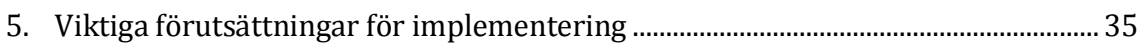

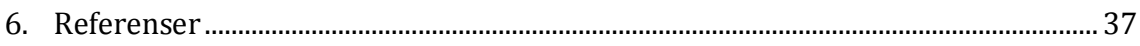

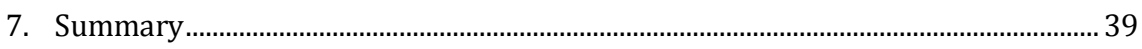

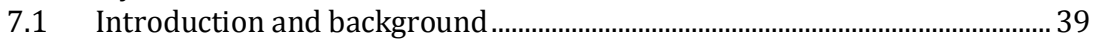

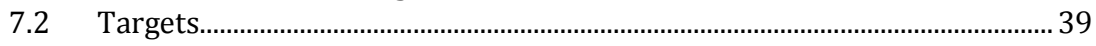

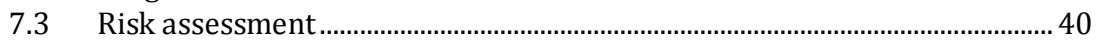

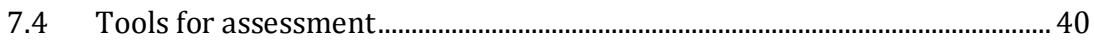

7.5 Use in the Nordic countries........................................................................ 41

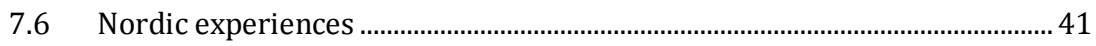

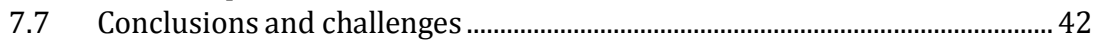

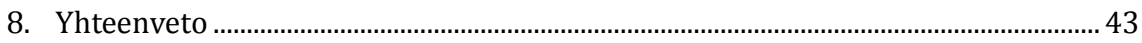

$8.1 \quad$ Johdanto ja tausta ............................................................................................. 43

8.2 Projektin tavoitteet.......................................................................................... 43

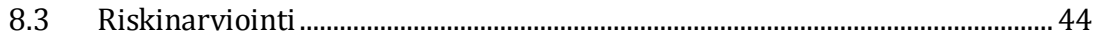

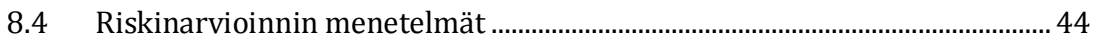

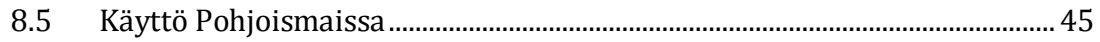

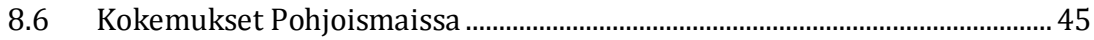

8.7 Päätelmät ja haasteet ............................................................................................. 46

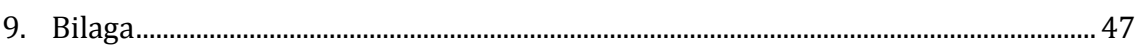

9.1 Bilaga 1: Våldsstatistik............................................................................... 47

9.2 Bilaga 2: MARAK (Moniammatillinen riksinarvioinnin kokous).................. 49

9.3 Bilaga 3: SARA (Spousal Assault Risk Assessment) ....................................... 55

9.4 Bilaga 4: SARA:SV (Spousal Assault Risk Assessment: Short Version)........... 59

9.5 Bilaga 5: Beskrivning av omnämnda bedömningsinstrument...................... 63 



\section{Sammanfattning}

Många myndigheter möter våldsutsatta eller våldsutövare och kunde om de klarade av att identifiera våldet och dess omfattning - vidta åtgärder för att skydda våldsoffren. Att bedöma risker är dock mycket krävande. Ännu svårare är det att vidta effektiva åtgärder, i all synnerhet om en helhetsmässig uppfattning om den våldsutsattas situation saknas. Det nordiska myndighetsnätverket, som jobbar med frågor om våld i nära relationer, tog initiativet till ett samnordiskt projekt om metoder att bedöma risken för förekomsten av våld i parrelationer. Projektet har koordinerats av Institutet för hälsa och välfärd i Finland.

I denna rapport redogörs för nordiska myndigheters användning och erfarenheter av strukturerade instrument som används av professionella för att bedöma risken för förekomsten av våld i parrelationer. Rapporten berör riskbedömningsarbetet utifrån två centrala frågor:

- Använder myndigheterna strukturerade riskbedömningsinstrument?

- Om ja - vilka resultat har uppnåtts och vilka utmaningar har framkommit?

Avsikten är att genom de erhållna resultaten underlätta jämförelser mellan de nordiska länderna och möjliggöra ömsesidigt kunskapsutbyte.

Dagens riskbedömningsinstrument har vuxit fram ur en tradition av praktik om och forskning kring riskbedömning. Den huvudsakliga målsättningen för riskbedömning på individnivå är prevention och inte prediktion. Riskbedömningsarbetet handlar om att kartlägga risken för våld, uppskatta hur allvarlig den är och vilka följder det eventuella våldet kan få. Utgående från denna bedömning kan sedan nödvändiga åtgärder vidtas för att minimera risken för att våld brukas. Bedömningarna baserar sig på strukturerade och standardiserade frågor men fokus ligger på en kvalitativ bedömning av innehållet (i riskfaktorerna) snarare än på en mekanisk poängsummering.

De strukturerade, professionella bedömningsmetoder som myndigheter i Norden specifikt använder sig av vid partnervåld är MARAK och SARA resp. SARA:SV. Både polis och kriminalvård i Sverige har riktlinjer för användning av SARA:SV respektive SARA; i Norge finns planer att implementera instrumentet i samtliga polisdistrikt; i Danmark befinner 
sig implementeringen av SARA:SV i ett inledande skede medan Finland tagit i bruk MARAK-modellen och har planer på att implementera MARAK i hela landet.

I kartläggningen framgår dock att myndigheterna använder riskbedömningsinstrumenten i varierande grad. Där de strukturerade professionella instrumenten introducerats är erfarenheterna generellt sett goda. Arbetssättet förbättrar riskbedömningarna och underlättar även kommunikationen och samverkan både mellan myndigheter och mellan övriga aktörer. För att användningen av riskbedömningsinstrument ska bli så effektiv som möjlig krävs dock att arbetet organiseras systematiskt och att det är grundligt förankrat i verksamheten. Det är viktigt att arbetet sker med stöd av organisationens ledning och att särskilda ansvarspersoner utses för att koordinera arbetet. Implementeringen av verktygen bör ske långsiktigt och backas upp av kontinuerlig utbildning och fortbildning. Ett effektivt arbete förutsätter ett tillräckligt utbud av tjänster, liksom att det är klart vem som ansvarar för vad och att olika aktörer uppnår samstämmighet i fråga om behovet av möjliga åtgärder. 


\section{Förord}

I de nordiska länderna finns ett stort behov av samordning och av att utveckla metoder som används i arbetet mot våld i nära relationer. Ett betydande utvecklings- och forskningsarbete inom området pågår i Norden. Detta arbete kunde bättre utnyttjas både inom och utanför de nordiska länderna.

Det första nordiska nätverket mellan myndigheter som jobbar med frågor om våld i nära relationer grundades under Finlands ordförandeskap för Nordiska ministerrådet 2011. Det samnordiska nätverket fyller behovet av erfarenhets- och informationsutbyte eftersom många utvecklingsbehov är gemensamma. Det nordiska myndighetsnätverket utgör därmed ett ypperligt forum för fortsatt utvecklingsarbete på området.

Nätverket har påbörjat ett samnordiskt projekt om metoder att bedöma risker för våld i parrelationer. Det stora antalet kvinnor som i Finland blivit dödade av sin partner/ex-partner har lett till att den interministeriella arbetsgruppen för förebyggande av våld i nära relationer beslöt att vidta åtgärder för att förbättra bedömningen av risker för våld i parrelationer. Behovet att bedöma risk för våld föreligger även i de andra nordiska länderna. Fler exempel framkom på fall där myndigheternas åtgärder för att skydda offret för partnervåld försvårats av att förövaren avtjänat sitt straff i ett annat nordiskt land. Behovet av gemensamma riskbedömningsmetoder för att skydda offren bättre är uppenbart.

Det samnordiska projektet "Riskbedömning och säkerhetsåtgärder vid våld i parrelationer" har koordinerats av Institutet för hälsa och välfärd i Finland. Planeringen och förverkligandet av projektet skedde i samarbete med Nationellt centrum för kvinnofrid (NCK) i Sverige samt Justis- og beredskapsdepartementet och Helsedirektoratet i Norge. Projektet finansierades av Nordiska ministerrådet.

Projektets målsättning var att utbyta erfarenheter mellan myndigheter i Norden och vidareutveckla metoder för bedömning av risker. Projektets mål var att förbättra myndigheternas färdigheter att bedöma risker och förhindra upprepat partnervåld samt att skydda offren bättre. Målgruppen var alla de myndigheter som möter förövare eller offer för partnervåld.

Två arbetsseminarier arrangerades under projektets gång. Det första seminariet hölls i juni 2013 i Finland i samarbete med Hanaholmen - 
kulturcentrum för Sverige Finland. Det andra seminariet gick av stapeln i december 2013 i Norge. Projektet har utmynnat i denna rapport, som kartlägger olika, i Norden använda, metoder för bedömning av risk för upprepat partnervåld samt ger förbättringsförslag och rekommendationer för bättre bedömning av risker och förslag på åtgärder för att öka säkerheten vid parrelationsvåld. Projektarbetare Barbro Nordling har, i samarbete med projektets arbetsgrupp, sammanställt rapporten.

Rapporten är riktad till politiker, till myndigheter på alla nivåer och till alla dem som inom den offentliga sektorn och frivilligorganisationer jobbar med offer för och förövare av partnervåld.

\section{Helena Ewalds}

Utvecklingschef

Institutet för hälsa och välfärd

Finland

Line Nersnæs

Fagdirektør

Politiavdelingen, Justis- og

beredskapsdepartementet

Norge

Freja Ulvestad Kärki

Prosjektleder

Avdeling for Psykisk Helse og Rus

Helsedirektoratet

Norge

\section{Gun Heimer}

Föreståndare, professor

Nationellt centrum för kvinnofrid

Sverige

Hilde Marit Knotten

Seniorrådgiver

Politiavdelingen, Justis- og

beredskapsdepartementet

Norge 


\section{Inledning}

\section{Våld i parrelationer är ett utbrett problem}

Våld i parrelationer har följder som kan vara mycket allvarliga eller till och med dödliga. Våldet utgör ett allvarligt problem såväl globalt som i de nordiska länderna. Det dödliga våldet inom familjen sker vanligen i hemmiljö och offren är oftast kvinnor. Statistiken i de nordiska länderna över antalet fall av dödligt våld i nära relationer är inte helt jämförbara, eftersom definitionen av "dödligt våld" varierar mellan länderna och alla länder inte statistikför relationen mellan förövaren och offret. Översikten ger dock en bild av helhetssituationen. I Finland dödas i genomsnitt 21 kvinnor per år (2004-2013) av en man de har haft eller har en nära relation till. Motsvarande siffror för Sveriges del är 17, för Norges 7 och för Islands 0,4. Under en uppföljningsperiod på fyra år (2008-2011) har i Danmark dödats i genomsnitt 10 kvinnor per år. Omvända situationer, där mannen dödas av kvinnan, förekommer också men är betydligt ovanligare: i Finland dödas årligen i genomsnitt fem män, i Sverige fyra och i Norge en. På Island har under den 10 år långa uppföljningsperioden ingen man dödats av en kvinna han haft eller har en nära relation till. Se bilaga 1 .

Det krävs effektivare åtgärder för att förebygga det upprepade partnervåldet med risk för dödlig utgång. Partnervåld kan upptäckas i tid ifall myndigheterna klarar av att identifiera våldet och systematiskt använder strukturerade riskbedömningsmetoder. Syftet med riskbedömningen är att i tid identifiera och ingripa i de fall där risken för upprepat allvarligt våld förekommer. Många brott mot liv som riktats mot kvinnor kunde möjligen ha förebyggts ifall våldsspiralen avbrutits i tid.

\section{Rapportens upplägg}

I denna rapport redogörs för nordiska myndigheters användning och erfarenheter av strukturerade professionella instrument för riskbedömning för partnervåld. Avsikten är att genom de erhållna resultaten underlätta jämförelser länderna emellan och möjliggöra ömsesidigt kunskapsutbyte.

Fokus ligger främst på det riskbedömningsarbete som hänför sig till grava former av partnervåld samt partnervåld med risk för dödlig utgång. Denna typ av våld föregås i regel av en längre tids utsatthet. Ofta kan utsattheten ha varit känd bland flera myndigheter. Konsekvenserna 
av våldet kunde därför begränsas om våldet identifieras och åtgärdas redan av den första myndigheten som den våldsutsatta uppsöker. Till de myndigheter som våldsutsatta främst vänder sig till - antingen för hjälp för sin våldsutsatthet eller för stöd eller hjälp med något annat - hör bl.a. socialtjänst, hälso- och sjukvård och polis.

\section{Frågeställning}

Rapporten berör riskbedömningsarbetet inom dessa ovannämnda myndigheter och utgår från två centrala frågor:

- Brukar myndigheterna strukturerade riskbedömningsinstrument?

- Om ja - vilka resultat har uppnåtts och vilka utmaningar har framkommit?

\section{Sammandrag}

Myndigheterna använder riskbedömningsinstrument i varierande grad. Där det strukturerade professionella instrumentet introducerats är erfarenheterna generellt sett goda. För att användningen ska bli så effektiv som möjligt krävs dock att arbetet är a) systematiskt och b) grundligt förankrat i verksamheten. Erfarenheterna indikerar att kunskap, samsyn och ett gemensamt språk, samt strukturerat samarbete är förutsättningar för effektivt riskförebyggande arbete.

\section{Informationsunderlag}

Källor för rapporten utgörs i första hand av ifrågavarande myndigheters och övriga organs allmänt tillgängliga lägesbeskrivningar, inspektionsrapporter och utvärderingar. Materialet har främst sökts genom att konsultera myndigheternas hemsidor och publikationer med öppen tillgänglighet, till de delar där säkerhetsarbete i ärenden gällande partnervåld beskrivs. Där sådan skriftlig information saknats har organisationerna kontaktats för information om huruvida riskbedömningar utförs med hjälp av strukturerade bedömningsinstrument särskilt framtagna för partnervåld. En del information har också strömmat till i samband med de nordiska seminarier vilka ordnats under projektperioden.

\section{Begränsningar och avgränsningar}

Med hänsyn till den tid som avsatts för rapportens genomförande (ca en månad sammanlagt) avsågs ingen omfattande undersökning företas av riskbedömningsarbetet med instrument avsedda för partnervåld. Kartläggningen har komplicerats av att anvisade kontaktpersoner ibland och av varierande orsaker varit svåra att få tag på. Resultatet av arbetet är 
en faktasammanställning med målsättning att ge en överblick över det nuvarande läget och de utvecklingsbehov som framkommer.

Rapporten utgör ingen empirisk eller statistisk studie utan är en översiktlig kartläggning av bruket av strukturerade riskbedömningsinstrument för partnervåld. Fokus för kartläggningen är riskbedömning vid partnervåld och befintliga vetenskapligt utvärderade instrument. Övriga aspekter av riskbedömningsarbete ingår inte. Rapporten inbegriper ingen genomgång av instrumentens underlag i forskningen. 



\section{Riskbedömning: vad handlar det om?}

I många verksamheter som arbetar med våldsärenden är riskbedömning en naturlig och nödvändig del av arbetet. Man måste avgöra om det finns risk för att våld kommer att inträffa och hur pass allvarlig den risken är. Riskbedömningsarbetet är krävande och mycket står på spel - det kan vara en fråga om liv och död. I kontakt med förövare handlar det om att förebygga återfall medan man i kontakten med våldsutsatta syftar till att förebygga upprepad utsatthet.

Dagens riskbedömningsinstrument har vuxit fram ur en tradition av praktik av och forskning kring riskbedömning. Man talar vanligtvis om bedömningsinstrument i termer av första, andra, och tredje generationens riskbedömning.

De tidigaste riskbedömningarna var kliniska, ostrukturerade riskbedömningar. Att de var kliniska betyder att de ofta utfördes av kliniker (psykologer, psykiatriker osv.) och de ses som ostrukturerade i att de byggde helt på bedömarens kunskap, erfarenhet och kompetens snarare än på en standardiserad bedömningsmall eller evidens. Denna typ av bedömningar möttes redan på 1970-talet av kritik som hävdade att bedömningarna vara godtyckliga och oenhetliga.

Andra generationens riskbedömningar kallas också aktuariska bedömningar och utvecklades mot bakgrund av behovet av standardiserade modeller som skulle leda till mer samstämmiga bedömningar. $A k$ tuarisk avser att man använder en standardiserad modell som grund för bedömningen. Denna modell baserar sig på vägning av riskfaktorer (för våld, kriminalitet osv) som identifierats empiriskt i studier av personer som återfallit i brott. De aktuariska instrumenten fokuserar på prediktion av risk, dvs. att med så stor statistisk precision som möjligt uppskatta framtida risk på populationsnivå. De aktuariska instrumenten bedöms dock ha begränsad precision i bedömningar på individnivå, vilka behövs inom t.ex. polis eller socialvård. Dessutom uppvisar den aktuariska modellen begränsningar vad gäller träffsäkerhet, och risker bedöms som relativt statiska. Bland de aktuariska instrumenten finns bland annat VRAG (Violence Risk Appraisal Guide) samt Static-99 och Static-2002 (för sexuellt våld). 
Fokus på prediktion bland andra generationens bedömningsinstrument och den medföljande begränsningen i användbarhet har sedermera kritiserats. Detta har lett till att syftet med riskbedömning tydligare formulerats. Den huvudsakliga målsättningen för riskbedömning på individnivå är prevention och inte prediktion. För säkerhetsarbete innebär det ett misslyckande om predicerad risk visar sig korrekt (det vill säga att en förutspådd våldsgärning faktiskt inträffar). Den huvudsakliga målsättningen är att identifiera risk för att kunna förhindra att den materialiseras.

Den tredje generationens bedömningsinstrument har utvecklats utifrån insikter om de tidigare riskbedömningarnas styrkor och brister. De benämns ofta strukturerade, professionella bedömningsinstrument därför att de är en slags kombination av första och andra generationens styrkor i form av bedömarens kompetens respektive instrumentets struktur. Liksom andra generationens instrument är de evidensbaserade men syftet är att analysera vilka åtgärder som krävs för att förhindra upprepat våld, inte statistisk prediktion. Riskbedömningsarbetet handlar då om att kartlägga risken, uppskatta hur allvarlig den är och vilka följder eventuellt våld kan få, för att utgående från bedömningen kunna vidta åtgärder för att minimera risken. Bedömningar är strukturerade och standardiserade men fokus ligger på en kvalitativ bedömning av innehållet i riskfaktorerna snarare än en mekanisk poängsummering.

Det finns ett flertal strukturerade professionella bedömningsinstrument för att skatta risk i olika typer av våld, t.ex. HCR-20 (Historical, Clinical and Risk med 20 riskfaktorer) för generellt våld bland personer med psykisk störning, PCL-R (Psychopathy Checklist-Revised) för psykopati och SVR-20 (Sexual Violence Risk-20).

SARA/SARA:SV (Spousal Assault Risk Assessment respektive Spousal Assault Risk Assessment: Short version), SAM (Stalking Assessment and Management) och Patriark är exempel på de vanligaste riskbedömningsinstrumenten av tredje generationen vilka är avsedda för riskbedömning av återfall i partnervåld, stalking ${ }^{1}$ respektive hedersrelaterat våld. MARAC (Multi-Agency Risk Assessment Conference), i Finland kallad MARAK (moniammatillinen riskinarvioinnin kokous) ${ }^{2}$ är ett exempel på en integrativ modell för att bedöma risk för upprepad utsatthet och pla-

\footnotetext{
1 Förföljelse eller trakasserier t.ex. i form av ofredande, olaga intrång eller överträdelse av kontaktförbud. Lagstiftning kring fenomenet stalking varierar mellan olika länder.

2 Ung. multiprofessionellt riskbedömningsmöte.
} 
nera skyddsåtgärder, vilken bygger på informationsutbyte och samarbete mellan myndigheter.

Riskbedömningsarbetet bygger på att man identifierar våldsutsatthet och behöver därför ofta kopplas till någon form av praxis för att fråga om våld. 



\section{Lägesöversikt}

Riskbedömning är en naturlig del av arbetet med partnervåldsärenden inom många myndigheter. Dock har inte alla myndigheter tillgång till verktyg som kan effektivera och underlätta arbetet. Summariskt kan konstateras att det föreligger stor variation mellan myndigheterna och länderna i Norden angående bruket av strukturerade riskbedömningsinstrument i det våldsförebyggande arbetet (se tabell 1). Verktygen används inom delar av listade myndigheter och i inget fall används verktygen i alla fall där det vore möjligt. Det är också möjligt att det finns offentliga institutioner som använder verktyg som det inte varit möjligt att identifiera i samband med arbetet för denna rapport, t.ex. i fall där verktygen används i ringa omfattning.

Tabell 1. Användning av strukturerade, professionella bedömningsinstrument för partnervåld

\begin{tabular}{llll} 
& Social- och hälsovård & Polis & Kriminalvård \\
\hline Danmark & $\ldots \ldots$ & $\begin{array}{l}\text { SARA:SV, SAM, Patriark är i ett } \\
\text { inledande skede av implementering }\end{array}$ & \\
Finland & MARAK* & MARAK* & \\
Island & $\ldots$ & $-\ldots$ & $-\ldots$ \\
Norge & $-\ldots$ & SARA:SV* & $-\ldots$ \\
Sverige & SARA:SV & SARA:SV, SAM, Patriark & SARA \\
\hline
\end{tabular}

*Pilotprojekt har genomförts och modellen implementeras i större skala.

På flera håll används inga strukturerade verktyg. Vissa instanser använder strukturerade professionella bedömningsinstrument om än inte sådana som särskilt utvecklats för riskbedömning av partnervåld. Bland andra används HCR-20 (Historical, Clinical, Risk Management-20, för våldsbenägenhet hos kriminellt belastade med psykisk störning) och $P C L-R$ (Psychopathy Checklist Revised, för psykopati) och $L S / C M I$ (Level of Service/Case Management Inventory, för återfall i kriminalitet). Dessa används bland annat av polis och/eller kriminalvård i flera länder. En polismyndighet i Sverige har utarbetat en egen metod, Skånemodellen. Den icke-utvärderade och vetenskapligt ifrågasatta instrumentuppsättningen FREDA har tagits i bruk i delar av svensk socialtjänst. På Island 
har man inom Suðurnes polisdistrikt i samarbete med socialvården utvecklat ett strukturerat riskbedömningsinstrument för partnervåld.

Bland de vetenskapligt framtagna och utvärderade verktygen specifikt ägnade åt riskbedömning av partnervåld, vilka används av nordiska myndigheter, finns riskbedömningsinstrumenten SARA och den förkortade versionen $S A R A: S V$ samt modellen för riskbedömning och åtgärdsplanering MARAC/MARAK (se tabell 2). SARA:SV kompletteras av SAM och Patriark för riskbedömning av stalking (förföljelse) respektive hedersrelaterat våld.

\begin{tabular}{lll}
\multicolumn{1}{l}{ Tabell 2. MARAK och SARA:SV i översikt } & \\
\hline & MARAK & SARA:SV \\
\hline Målgrupp & Våldsutsatta (vuxna) & Förövare (vuxna) \\
Målsättning & Förebygga upprepad utsatthet & Förebygga upprepade våldshandlingar \\
Risktyp & $\begin{array}{l}\text { Partnervåld (eller hot om) innefattar } \\
\text { hedersrelaterat våld, stalking }\end{array}$ & Partnervåld (eller hot om) \\
& Delvis & \\
Omfattar barn & $\begin{array}{l}\text { Yrkesverksamma vid myndigheter där } \\
\text { man möter våldsutsatta }\end{array}$ & Polis, i någon mån socialtjänst o.d. \\
Användare & $\begin{array}{l}\text { Checklista för riskbedömning blankett } \\
\text { för samtycke manualer }\end{array}$ & Checklista för riskbedömning manual \\
Material & Ja & Ja \\
\hline
\end{tabular}

Användning av SARA:SV föreskrivs svensk polis. Rikspolisstyrelsen har förtydligat sina riktlinjer så att riskbedömningar skall göras i kontakt med brottsoffer samt att om en initial bedömning indikerar behov av en strukturerad bedömning skall en sådan utföras. Utredningar visar dock att arbetet långt ifrån alltid sker i enlighet med föreskrifterna. SARA:SV har utprövats i ett pilotprojekt av norsk polis och skall gradvis införas i alla Norges polisdistrikt. Danmarks polis arbetar på en framtida implementering av SARA:SV. Också SAM och Patriark används av svensk polis och inom dansk polis ingår verktygen i planerna för implementering av SARA:SV. Svensk kriminalvård föreskriver användning av SARA.

MARAK-modellen har tagits i bruk i Finland. För närvarande finns multiprofessionella MARAK-team på elva orter, med bland annat polis, hälso- och sjukvård samt socialvård involverade, samt frivilligorganisationer som jobbar med våldsoffer. Regeringen har i sitt program för perioden 2011-2015 beslutat att MARAK gradvis skall implementeras i hela landet. Institutet för hälsa och välfärd koordinerar arbetet fram till utgången av 2015. Det finns stort intresse bland institutioner som jobbar med våldsoffer att ta i bruk metoden. 
I de övriga nordiska länderna används strukturerade metoder i begränsad mån eller relativt osystematiskt. Ett stort behov av verktyg för att stödja och underlätta arbetet framkommer dock genom de egenhändigt utvecklade verktyg och metoder som på många håll tagits i bruk.

Riskbedömning förutsätter att våld först identifierats. Polis stöter vanligtvis på uppenbarade former av våld men i andra verksamheter är våldsutsattheten ofta mindre synlig. På många håll har man infört eller planerar att införa rutinfrågor om våldsutsatthet ${ }^{3}$ i verksamheter där man möter personer som kanske lever med våld eller hot om våld.

I Finland ingår rutinfrågor om våld i förordningen om rådgivningsverksamhet samt skol- och studenthälsovård. Institutet för hälsa och välfärd har i sina nationella riktlinjer för arbetet med våld i nära relationer rekommenderat att man systematiskt ställer frågan om upplevelser av våld och har även sammanställt ett arbetsverktyg. Avsikten på nationell nivå är också att förbättra dokumenteringen och statistikföringen av våld inom social- och hälsovården både lokalt och nationellt.

I Sverige är Socialstyrelsens vägledning för att upptäcka våld i skrivande stund ute på remiss. I dokumentet påpekas att våld måste identifieras oftare än nu både inom hälso- och sjukvård samt socialtjänst, liksom att orosanmälningar om barn som far illa måste öka inom hälsooch sjukvård samt socialtjänst. Sakkunniga på området betonar att man bör ställa frågan om våld som en del i anamnesen och för att säkerställa adekvat utredning och behandling, eller för att anpassa stödet inom socialtjänsten till individens behov.

I nuläge förs en diskussion i Norge om införandet av verktyg för rutinfrågor om våld $i$ ett läge där utbudet av tjänster ännu är outvecklat. Sakkunniga betonar att det är av avgörande betydelse att kompetensen och utbudet av tjänster utvecklas parallellt med implementeringen av verktyg för att ställa rutinfrågor om våld.

\footnotetext{
3 Detta har ibland kallats "screening". Termen har dock mött kritik i sammanhanget, bl.a. eftersom att fråga om våldsutsatthet, till skillnad från det mer neutrala screening för olika åkommor, i sig är en intervention.
} 



\section{Styrkor respektive utmaningar vid användningen av MARAK respektive SARA/SARA:SV}

\section{$3.1 \mathrm{MARAK}^{4}$}

På initiativ av den interministeriella arbetsgruppen för förebyggande av våld i nära relationer genomförde Institutet för hälsa och välfärd ett pilotprojekt i Finland 2010-2011 med den multiprofessionella riskbedömningsmodellen MARAC (multi-agency riskassessment conference), i Finland MARAK (moniammatillinen riskinarvioinnin kokous). ${ }^{5}$

Fokus i modellen ligger på den våldsutsattas säkerhet och brottsförebyggande är underordnat detta syfte. Ansatsen är dubbel och bygger dels på identifiering av våld och riskbedömning, dels det multiprofessionella arbetet med säkerhets- och stödåtgärder där risk identifierats (Robinson 2003; Piispa, Tuominen och Ewalds 2012; CAADA 2013).

Arbetsmetoden innefattar ett riskbedömningsformulär och en blankett för klientens samtycke. Riskbedömningen genomförs med hjälp av bedömningsformuläret i samtal med den våldsutsatta. Bedömaren kan skatta situationen till hög risk oavsett om formulärets kriterier uppfylls, utifrån en helhetsbedömning av den våldsutsattas situation. Bedömningen görs på basis av:

- våldsoffret har gett 14 eller flera ja-svar på frågorna som ingår i riskbedömningsinstrumentet

- bedömarens helhetsbedömning för att risken för våld är hög

- polisen har under de senaste 12 månaderna gjort åtminstone tre utryckningar till familjen.

4 En närmare beskrivning av MARAK-modellen finns i bilaga 2.

5 I denna rapport används akronymen MARAK för den finländska modellen. 
Vid hög risk skickas ärendet med klientens samtycke till den multiprofessionella MARAK-arbetsgruppen. I den finländska tillämpningen sker behandlingen av ärendet i MARAK alltid med klientens skriftliga samtycke, medan riskbedömningen görs oberoende av om klienten ger sitt samtycke eller inte.

Riskbedömningsformuläret tillhandahålls på finska, svenska, engelska och ryska. Den nationella koordineringen och utbildning ordnas i regi av Institutet för hälsa och välfärd. Verksamhet finns i dagsläge på elva orter och modellen implementeras på övriga orter i takt med orternas eget initiativ, med tanken att den så småningom ska användas i hela Finland.

\subsubsection{Samverkan utgör utgångspunkten för metoden}

I rapporten från det ettåriga MARAK-pilotprojektet (Piispa, Tuominen och Ewalds 2012), uppges följande positiva erfarenheter:

- Förbättrad arbetsprocess.

- De involverade får en bättre helhetsbild av offrets situation.

- Den våldsutsatta själv kan se sin situation tydligare.

- Möjliggör beslut om åtgärder baserade på information.

- Kunskapen om andra instansers arbetsuppgifter blir större.

- Informationsflödet och samarbetet mellan olika instanser förbättras.

En del frågor uppstår dock kring sekretess och tystnadsplikt, och under pilotprojektperioden framkom osäkerhet kring hur sekretessfrågor ska hanteras i myndighetssamverkan. Piispa, Tuominen och Ewalds (2012) konstaterar att tydlig lagstiftning kring myndigheters informationsutbyte och informationslagring behövs.

I de slutsatser som dras i pilotprojektet betonas att det är viktigt att göra arbetet till rutin och tydligt strukturerat. Man bör ge tydlig form åt den multiprofessionella arbetsgruppen genom att utse ordförande, sekreterare och medlemmar. Som minimikrav anges att polis, social- och hälsovård, skyddshem (kvinnojourer) och övriga organisationer som erbjuder stödtjänster till offret bör finnas representerade. Viktigast bland social- och hälsovårdsenheter är barnomsorg, socialvård och socialjour, tjänster inom mentalvård och missbrukarvård, primärhälsovård samt sådan jourverksamhet där man ofta påträffar akuta fall. En förutsättning för det multiprofessionella MARAK-samarbetet är att det ordnas tillräcklig utbildning såväl för dem som ingår $i$ MARAKarbetsgrupperna som för övrig personal inom social- och hälsovården samt polisväsendet. 
Rapporten konkluderar att väl organiserat arbete resulterar i att riskbedömning enligt MARAK-praxis inte heller upplevs som betungande eller tidskrävande (Piispa, Tuominen och Ewalds 2012). Arbetet för ordförande och sekreterare är mer omfattande men upplevdes inte som ett problem. MARAK-arbetet har inkorporerats i deltagarorganisationernas verksamheter utan särskild finansiering eller tilläggsresurser (ibid.). I Storbritannien har man gjort en uppskattning av kostnadseffektiviteten i MARAC-arbetet på basis av tillgänglig forskning. Rapporten Saving lives, saving money: MARACs and high risk domestic abuse (CAADA 2010) beräknar att varje spenderat pund kan resultera i en besparing på sex pund av samhälleliga medel. Uppskattningen anges vara försiktig och gäller enbart ekonomiska besparingar (CAADA 2010; Steel, Blakeborough och Nicholas 2011).

\subsubsection{Gör bruket av verktyg till en rutin}

Riskbedömningen förutsätter att våld identifierats. För att nå ut till flera våldsutsatta rekommenderas i utvärderingen av pilotprojektet att man utöver MARAK-modellen systematiskt inför frågor om våldsutsatthet för att kartlägga klientens situation. Ett frågeformulär har utformats och har sedermera införts som praxis.

MARAK-riskbedömningsblanketten upplevdes som ett effektivt verktyg för att kartlägga risk- och hotbild också i de fall ärendet inte gick vidare till MARAK-behandling. Längd och utformning av blanketten har enligt rapporten fătt gott betyg. Däremot hade användningen av blanketten under pilotprojektet ännu inte blivit rutin; osäkerhet förekom om när den ska eller kan användas. Blanketten har emellanåt använts främst för de fall där man redan på basis av förhandsinformation kunnat anta att risken för upprepat våld är hög. Meningen är dock att blanketten ska vara ett verktyg just för att kunna identifiera högriskfallen bland alla fall av partnervåld (Piispa, Tuominen och Ewalds 2012).

\subsubsection{Våldsutsattas erfarenheter}

För de våldsutsatta innebar arbetet bland annat att det räckte för dem att ha kontakt med en instans för att ändå kunna få hjälp från flera organisationer. Det framkommer i rapporten att de utsattas säkerhet förbättrats. En stor andel, 80 \%, av dem som deltagit i projektet gjorde inga nya våldsanmälningar inom de närmaste sex månaderna. Orsakerna till detta varierar sannolikt. Uteblivna anmälningar är inte heller alltid ett tecken på att våldet upphört. De våldsutsatta som kunde nås, intervjuades sex 
månader efter att deras ärende behandlats i MARAK. Då framkom att flera som inte längre utsattes för fysiskt våld ändå blev utsatta för förföljelse bland annat i form av dödshot eller hot om självmord från förövarens sida, främst genom telefonsamtal, SMS, e-post eller brev (Piispa, Tuominen och Ewalds 2012). Upprepat våld var vanligare bland dem som hade barn med förövaren och således var tvungna att upprätthålla kontakt med förövaren (ibid.). I slutrapporten konstateras det också vara viktigt med uppföljning och fortsatt stöd.

I utvärderingen av pilotprojektet nämns exempel på de vanligaste åtgärder som vidtagits, däribland (med början från de mest frekventa) hänvisning till skyddshem (kvinnojour), stöd i form av gruppsamtal, stöd från tjänster inom socialarbete och socialskydd, besöksförbud, hjälp med att ordna ny bostad och ekonomiskt stöd. Ibland kunde inget stöd erbjudas, som i fall där klienten var ovillig att ta emot erbjudna tjänster eller redan hade erhållit tjänsterna (Piispa, Tuominen och Ewalds 2012). För en klar bild av åtgärdernas effektivitet måste kontinuerlig uppföljning genomföras (ibid.).

Somliga klienter gav inte sitt samtycke till MARAK-behandling och några avvek från överenskomna åtgärder. De professionellas osäkerhet om tillämpningen av arbetsmetoden kan ha bidragit till detta. Kanske fick klienterna bristande information om vad ärendets behandling i MARAK innebär, varför en del inte gav sitt samtycke under pilotprojektet.

\subsubsection{Stödpersonens roll}

För att minska en eventuell upplevelse hos klienten av att bli objekt för hjälpåtgärder, med minskat eget handlingsutrymme som följd, sågs det som centralt att samarbeta tätare med klienten. Ett steg i denna riktning vara att utveckla stödpersonsverksamhet. Stödpersonen agerar då t.ex. som klientens representant under MARAK-möten (klienterna deltog inte under pilotprojektet) och finns som stöd för offret under och efter arbetet. Under pilotprojektet organiserades verksamheten på lite olika sätt. På några orter hade en stödperson utsetts under första MARAK-mötet, vilket dock inte befanns vara ändamålsenligt, eftersom personen då inte kunde agera representant för klienten. I MARAK-arbetet utses därför numera en stödperson alltid i samband med att fallet hänvisas till MARAK. Ytterligare en förändring som några orter infört efter pilotprojektet är att klienten med eget samtycke kan närvara vid MARAK-mötet. Detta sker dock enbart i väl övervägda fall. Stödpersonen bör vara en professionell med de specialkunskaper som krävs och därtill aktivt ta kontakt med klienten (Piispa, Tuominen och Ewalds 2012). I Finland 
finns ingen särskild organisation som står för stödpersonsverksamheten motsvarande den brittiska IDVA (Independent Domestic Violence Advocacy). Stödpersonsverksamheten organiseras därför i samarbete med frivilligorganisationer såsom Brottsofferjouren.

\subsection{SARA, SARA:SV6}

Mätinstrumentet SARA finns i både en längre (SARA) och en kortare (SARA:SV) version. Den mer omfattande versionen SARA (Spousal Assault Risk Assessment) används inom svensk kriminalvård. SARAanvändning föreskrivs:

- vid personutredning, och om ingen gjorts i detta skede

- som underlag för VSP (verkställighetsplan)

- vid urval till programmet IDAP (Integrated Domestic Abuse Programme)

- som möjligt hjälpmedel inför beslut under verkställigheten (det kan gälla permission, besök av eller kontakt med brottsoffer, övervakningsbeslut $\mathrm{mm}$ ).

Instrumentet rapporteras vara ett gott stöd för arbetet (Grann 2007). Dock framkommer att SARA och andra motsvarande strukturerade instrument i praktiken används i långt ifrån alla föreskrivna fall. Detta gäller såväl inom frivård som anstalt (Svensson och Person 2011; Holm och Jukic 2013).

SARA-instrumentet är relativt omfattande och ställer krav på kliniskt kunnande hos användaren, bland annat för att bedöma klientens psykiska tillstånd. I polisiär verksamhet har SARA upplevts svårhanterlig både beträffande sin längd och sin utformning. SARA har därför vidareutvecklats för att möta de utmaningar som riskbedömningsarbetet ställs inför i polisiär verksamhet i form av instrumentet B-SAFER (Brief Spousal Assault Form for the Evaluation of Risk). SARA:SV (Spousal Assault Risk Assessment: Short version) är den nordiska översättningen och bearbetningen av instrumentet B-SAFER. SARA:SV är den version som idag används av svensk respektive norsk polis (Kropp, Hart \& Belfrage 2008; 2011). Detta verktyg inkluderar, utöver riskfaktorer

${ }^{6}$ En närmare beskrivning av SARA i bilaga 2 och SARA:SV i bilaga 3. 
kopplade till förövaren, sårbarhetsfaktorer hos den våldsutsatta, vilka visat sig vara viktiga för att kunna bedöma risken för upprepat våld (Belfrage och Strand, 2008). Instrumentet kompletteras av SAM (Stalking Assessment and Management, för olaga förföljelse) och Patriark (för hedersrelaterat våld).

\subsubsection{SARA:SV för bättre bedömningar och ökad kompetens}

Under de tidiga försöken i Sverige med versioner av SARA-instrumentet framkom att polisen blev mer professionell och gjorde bättre riskbedömningar. De satte också in flera och mer omfattande åtgärder ju fler riskfaktorer som iakttagits (Belfrage och Strand 2001; 2003). Liknande erfarenheter rapporteras i de utvärderingar som gjorts av de norska pilotprojekten. Som fördelar nämns bland annat att våldsutsattheten görs synligare samt att högriskfallen blir handgripliga. Metoden uppges också ge bättre rutiner för polisens interna arbete och för samarbetet med externa organ (Oslo politidistrikt 2012; Politidirektoratet 2012) samt att arbetet blir mer långsiktigt och helhetsmässigt (Nøttestad och Lynum 2012). Intervjuer med verksamma poliser visar också att SARA:SV upplevdes som ett gott stöd för att ställa relevanta frågor snarare än som en belastning (t.ex. i form av att stjäla tid från övriga uppgifter) (Nøttestad och Lynum 2012). Sammanfattningsvis innebär användningen av SARA:SV:

- Fler och mer omfattande åtgärder.

- Våldsutsattheten synligare.

- Högriskfallen mer handgripliga.

- Bättre rutiner för polisen internt.

- Bättre samarbete med övriga organ.

- Mer långsiktighet $i$ arbetet.

Användning av instrumentet ingår i riktlinjerna för svenska polisens arbete med riskanalys i partnervåldsärenden. I dagsläge utför de flesta polismyndigheter strukturerade bedömningar i åtminstone någon mån med detta verktyg. Få polismyndigheter arbetar dock systematiskt med strukturerade bedömningsverktyg trots riktlinjerna. Även om många myndigheter har utformat tjänsteföreskrifter kring bruket av bedömningsverktyg, följs de sällan till fullo (Westlund 2010, Rikspolisstyrelsen 2010b och 2012; Lindgren och Strandell 2010). De flesta polismyndigheter har genomfört SARA:SV-utbildningar (utöver SARA:SV har även utbildningar ordnats vilka omfattat SAM och Patriark). Rikspolisstyrel- 
sen (2010b) rekommenderar att utbildning i SARA:SV omfattar två dagar. I Norge har man efter pilotprojekt med instrumentet i Stovner respektive Horten politistasjoner, (Kropp, Hart och Belfrage 2011), beslutat att gradvis införa det i alla polisdistrikt.

Också inom delar av svensk socialtjänst används instrumentet SARA:SV. Instrumentet är inte fullt ut ägnat åt arbete inom socialtjänst. Bland annat påpekas i en rapport från Sveriges Kommuner och Landsting (Eriksson, Berg och Wallqvist 2011) att instrumentet SARA:SV inte i alla hänseenden är ägnat socialtjänstens arbete och att användande kan kompliceras av snävare tillgång till informationskällor. Bedömningen av huruvida barn är utsatta för risk kan behöva kompletteras med annan information (ibid.). Att andra myndigheter använder samma verktyg som polisen främjar dock ett gemensamt språk och således också samarbetet mellan myndigheter (Carlsson 2013). För polisiär användning kan bedömningar kompliceras ifall klienten lider av psykisk instabilitet eller personlighetsstörning, eftersom underlaget då kan vara bristfälligt p.g.a. att delgivning av kliniska diagnoser skyddas av sekretess (Westlund 2010).

\subsubsection{Arbetet måste ses $\mathrm{i}$ helhetsperspektiv}

För att riskbedömningsarbetet ska löpa och ge resultat framhålls vikten av ett helhetsperspektiv gällande både hur verksamheten organiseras (från utbildning av bedömare till uppföljning av arbetet) och hur arbetsprocessen läggs upp (från initial bedömning till utgången i form av skyddsåtgärder samt uppföljning) (Lindgren och Strandell 2010; Westlund 2010; Strandell 2013). Enligt granskningar av polisens arbete inom många polismyndigheter i Sverige förekommer brister gällande både organiseringen av verksamheten och uppläggningen av själva arbetsprocessen. (Westlund 2010; Lindgren och Strandell 2010; Rikspolisstyrelsen 2010b). Lindgren och Strandell (2010) rapporterar att det inom ett flertal polismyndigheter råder oklar ansvarsfördelning ifråga om vem som ska ansvara för arbetet med strukturerade hot- och riskbedömningar. Ofta kan verksamheten vara fragmenterad så att olika personer har hand om olika faser av riskbedömnings- och riskhanteringsarbetet, inklusive uppföljningen, utan inbördes samverkan eller samordning (ibid.). Det framgår också att skillnaderna är små mellan polismyndigheter gällande regelmässigheten i arbetet med riskbedömning, oavsett hur omfattande utbildningssatsningar som gjorts, och att satsningarna blivit punktinsatser snarare än lagt grunden för ett systematiskt arbetssätt (Lindgren och Strandell 2010). 


\subsubsection{Initial bedömning för att identifiera behovet av strukturerad bedömning}

Arbete med SARA:SV förutsätter ett system för initiala bedömningar, så att strukturerade bedömningar görs endast då de behövs. Rikspolisstyrelsen (2010a) anger i sina riktlinjer att SARA:SV kan användas som stöd för en initial bedömning av den omedelbara situationen och för att sålla fram fall som kräver vidare utredning. Enligt rapporter genomförs basutredningen vid akuta situationer (som förutsätter skyddsåtgärder), medan mindre alarmerande fall i högre grad riskerar att inte utredas (Westlund 2010; Lundgren \& Strandell 2010). Det norska pilotprojektet använde en "mini-SARA", som utgjordes av ett urval av riskfaktorerna vid akut bedömning. Till dem hörde frågor om aktuellt eller tidigare våld och hot (med eller utan vapen), eskalering av våldet, brott mot besöksförbud, rusmissbruk samt psykiska problem. Polisen i yttre tjänst fick utbildning i hur SARA:SV används, bl.a. genom att öva att fylla i checklistan i sin helhet och att göra själva bedömningen.

\subsubsection{Utbildning och ansvarsfördelning}

Enligt svenska Rikspolisstyrelsens (2012) rekommendationer bör SARA:SV utföras av personal som särskilt utsetts för ändamålet och utbildats i att använda instrumentet. Utredningar kan vara omfattande och därmed även resurskrävande. Arbetar personalen kontinuerligt med riskbedömning ökar dess kompetens och dess kunnande upprätthålls och utvecklas. Samtidigt bör riskbedömningsarbetet fördelas på flera personer; dels för att säkra kvaliteten på riskbedömningarna, dels för att säkra kontinuiteten så att inte riskbedömningsarbetet står och faller med en enda person. Även det norska pilotprojektet understöder denna arbetsfördelning (Oslo Politidistrikt [2012]). Att arbeta i par ses också som en fördel, i synnerhet vid stöd av mindre erfarna bedömare. Genom att svar och slutbedömningar diskuteras tillsammans ökar träffsäkerheten i bedömningar (Westlund 2010).

\subsubsection{Koppling mellan bedömning och åtgärder}

För att de strukturerade riskbedömningarna ska fungera måste de också tydligt kopplas till skyddsåtgärder. Möjliga skyddsåtgärder kan bygga på administrativt skydd (såsom skydd av personuppgifter), tekniskt skydd (larmtelefon o.d.), övervakning (t.ex. rondering) eller skyddat boende. Till de vanligare skyddsåtgärderna hör besöksförbud, larmtelefon (eller motsv.) och rondering (ofta med hund) kring den hotades bostad, skydd- 
dat boende, eller skyddad adress/skyddat telefonnummer (Rikspolisstyrelsen 2012; Westlund 2010).

Åtgärderna måste också anpassas till den hotade, varför samarbete med henne ses som en förutsättning (Westlund 2010). De flesta svenska polismyndigheter har någon form av säkerhetssamtal med den våldsutsatta för att diskutera möjliga åtgärder; vid några polismyndigheter genomförs också motivationssamtal som syftar till att motivera våldsutsatta kvinnor att hålla fast vid sin anmälan (ibid.).

Eftersom skyddsåtgärder inbegriper många aktörer förutsätter arbetet samverkan mellan polismyndigheterna liksom med andra myndigheter och ideella organisationer såsom socialtjänst och kvinnojourer. För norska polisens pilotprojekt med SARA:SV listas bland andra NAV, barnomsorg, kriscenter (kvinnojourer) som samarbetsparter i riskbedömnings- och hanteringsarbetet.

Enligt Brottsförebyggande rådets (Brå) utredning är länken mellan strukturerade riskbedömningar och beslut om skyddsåtgärder alltför svag hos svensk polis. Inget i studien tyder på att arbetet med strukturerade riskbedömningsinstrument skulle ha lett till att flera kvinnor erbjudits skyddsåtgärder. Bedömare vet inte heller alltid vem som är mottagare av bedömningen, vilket kan försvaga helhetsuppfattningen av verksamheten och urholka motivationen bland personalen (Westlund 2010). En möjlig delförklaring till den bristfälliga kontakten mellan bedömare och beslutstagare för skyddsåtgärden kan bero på ansvarsfördelningen för skyddsåtgärderna. Exempelvis besöksförbud, som hör till de mest använda åtgärderna, utfärdas av åklagare. Enligt Brå kunde polis och, i det här fallet, åklagarmyndigheten diskutera praxis för riskbedömning och möjligheter till informationsöverföring (ibid.).

\subsubsection{Uppföljning}

Risk för att utsättas för våld varierar över tid och därför behöver riskoch behovsbedömningar följas upp kontinuerligt (minst var sjätte månad enligt manualen för SARA:SV). Effektivt arbete med riskbedömningar kräver dessutom att också verksamheten kontinuerligt följs upp och utvärderas. Detta säkras genom tydliga målsättningar, vilka kan granskas. En målsättning kunde t.ex. vara att minska den upprepade utsattheten för specifika brottstyper (Rikspolisstyrelsen 2010a). Löpande uppföljning av partnervåldsärenden inom polisen skulle också underlätta studier om effekterna av riskbedömning och skyddsåtgärder (Westlund 2010). 



\section{Avslutande reflektioner}

Många myndigheter möter våldsutsatta eller våldsutövare. Om våldet identifieras och dess omfattning uppskattas, kan åtgärder vidtas för att skydda våldsoffer. Att bedöma risk är dock mycket krävande. Ännu svårare är det att vidta effektiva åtgärder, i all synnerhet utan en klar och helhetsmässig uppfattning om den våldsutsattas situation. I fall där strukturerade professionella metoder implementerats är de involverade generellt sett positivt inställda till de införda verktygen. Utmaningen ligger i att säkra att de nya arbetssätten förblir en permanent del av verksamheten också på sikt. Risken är att riskbedömningsarbetet står och faller med eldsjälar eller blir punktinsatser som upphör så snart projektet tar slut eller enbart ses som ytterligare en blankett att fylla i en blankett man snart glömmer att existerar.

\subsection{Vilka är fördelarna med metoderna?}

De strukturerade, professionella bedömningsmetoderna specifikt ägnade åt partnervåld vilka används i nordiska myndigheter är MARAK och SARA resp. SARA:SV. För riskbedömning i angränsande problemområden används SAM (olaga förföljelse) och Patriark (hedersrelaterat våld) som komplement till SARA:SV. Arbetssätt som är strukturerade enligt modellen för MARAK respektive instrumentet SARA:SV upplevs både förbättra riskbedömningar och underlätta kommunikationen och samarbetet myndigheter emellan samt med övriga aktörer.

Till de uppenbara fördelar som riskbedömning med dessa strukturerade metoder erbjuder hör:

- Mer professionella riskbedömningar.

- Förbättrad helhetsbild av klienters våldsutsatthet.

- Bättre underbyggda förslag för skyddsåtgärder.

- Ökad kompetens kring partnervåld.

- Potential för bättre kommunikation mellan myndigheter vilket underlättar samverkan. 
Effektivt riskbedömnings- och riskhanteringsarbetet betyder i praktiken förbättrat skydd för våldsutsatta men också t.ex. möjlighet för de utsatta att klarare se sin situation. Ökad kompetens kring partnervåld och utsatthet bäddar även för ett sakligare bemötande av offren. För yrkesverksamma är metoderna kompetenshöjande och har potential att skapa större tillit mellan klient och professionell. Välstrukturerat arbete kan också öka motivationen. Ur samhälleligt perspektiv erhålls enorma effekter av det förebyggande arbetet, vilket minskar många medborgares såväl emotionella som fysiska lidande. Dessutom kan arbetet med professionella strukturerade metoder medföra effektivering av personalresurser och därmed även på lång sikt ekonomiska besparingar.

\subsection{Vilka utmaningar har man mött?}

Även om riskbedömningsinstrument är träffsäkra och kan erbjuda stora förbättringar förblir deras värde marginellt t.ex. då motivationen att använda dem är låg eller då det råder oklarhet angående ansvarsfördelning och rutiner. En bred bas av kunskap om våld i nära relationer gör att fler kan använda bedömningsverktygen, vilket i förlängningen också gör strukturen på arbetet mindre sårbar vid organisationsförändringar. Riskbedömning innefattar också riskhantering, varför det måste stå klart vilka skyddsåtgärder som finns och vem som ansvarar för dem. Till de grundläggande utmaningarna hör:

- Att verktygen inte används.

- Att metoder implementerats men att det är oklart när och hur de ska brukas.

- Oklarheter kring möjliga skyddsåtgärder eller vem som ansvarar för åtgärderna.

- Våldsutsattas medverkan - att den våldsutsattas egen röst inte blir hörd. 


\section{Viktiga förutsättningar för implementering}

En grundläggande förutsättning för att de strukturerade metoderna skall kunna användas effektivt är att verksamheten organiseras helhetsmässigt. Det är viktigt att arbetet sker med stöd av organisationens ledning samt att vissa personer utses att ansvara för koordineringen av arbetet.

Implementeringen av verktyg bör ske långsiktigt, så att de t.ex. backas upp av kontinuerlig utbildning och fortbildning, att användningen av instrumenten förankras i verksamheten, att samverkan med olika aktörer är utarbetad och tydlig för alla parter, och att resultaten följs upp kontinuerligt.

\section{Långsiktighet $\mathrm{i}$ implementeringen}

- Ledningens stöd.

- Kontinuerlig utbildning/fortbildning.

- Riskbedömningsarbetet förankrat i verksamheten.

- Samverkan tydlig och välplanerad.

- Resultaten följs upp.

För arbetsprocessen betyder det att man bör skapa tydliga rutiner och en klar ansvarsfördelning alltifrån den initiala bedömningen eller rutinfrågan om våld, till utgången i form av skyddsåtgärder. Effektivt säkerhetsarbete förutsätter ett tillräckligt utbud av tjänster, inkluderat särbehov (t.ex. sådana som fordras i fråga om språk, missbruk, funktionshinder, psykisk sjukdom), en klar ansvarsfördelning, samt samstämmighet bland de involverade i fråga om behovet av åtgärderna.

\section{Arbetsprocessen helhetsmässigt planerad}

- Tydliga rutiner.

- Klar ansvarsfördelning.

- Tillräckligt utbud av tjänster, också för särbehov.

- Samstämmighet i fråga om behov av och ansvar för tjänster. 
Om arbetet med riskbedömningsmetoderna implementeras på bred bas och resulterar i ökad säkerhet för våldsutsatta ökar också motivationen bland både personal och klienter att använda sig av metoderna. För klienters del är det också viktigt att arbetet sker i samförstånd med dem så att deras motivation till deltagande bibehålls och åtgärderna anpassas till deras behov och möjligheter. Till sådana verksamhetsformer hör bland andra svenska polisens säkerhetssamtal med våldsutsatta och stödpersonverksamheten i MARAK-arbetet. Med tanke på att mödrars och barns säkerhet är beroende av varandra är det också centralt att barn uppmärksammas i riskbedömningsarbetet. 


\section{Referenser}

Belfrage H \& Strand S. (2001) Polisiär bedömning av risk för upprepat partnervåld. Resultat av ett års arbete med strukturerade riskbedömningar enligt SARA i Kalmar, Kronoberg och Blekinge län. Sundsvall: Rättspsykiatriska Regionkliniken.

CAADA (2010) Saving lives, saving money: MARACs and high risk domestic abuse REFERENCED VERSION. [S.l.]: CAADA. Tillgänglig elektroniskt på http://www.caada.org.uk/policy/Saving_lives_saving_money_FINAL_VERSION.pdf (senast hämtad 13.12.2013).

Carlsson, H. (2013) Brottsofferjourernas Riksförbunds synpunkter på Socialstyrelsens bedömningsinstrument FREDA. Rapport 2013. [Stockholm]: Brottsofferjourernas Riksförbund.

Eriksson M, Berg L. och Wallqvist A. (2011) Våldsförebyggandearbete med män. En kunskapsöversikt. [Stockholm]: Sveriges Kommuner och Landsting.

Gosenius, S. (2013) Metodstöd för riskanalyser vid våld på individnivå. Taktisk ledning. Dnr AA 489-5160/09. [Malmö]: Polismyndigheten i Skåne.

Grann, M. (2007) SARA - riskfaktorer för partnervåld. En jämförelse mellan män i England och Sverige. Kriminalvårdens forskningskommitté: Rapport 22. Norrköping: Kriminalvården.

Jensson Jóhannes. Opublicerad statistik från polisen på Island. 24.2.2014.

Justitsministeriets Forskningskontor. (2014) Drab i Danmark 2008-2011.

Kropp, R. et al. (2011) Bedømming av risikoen for gjentatt partnervold (SARA:SV), versjon 2. Brukermanual. Oslo: Politihøgskolen.

Kropp, R., Hart, S.D., Belfrage , H., (2008). Bedömning av risk för upprepat partnervåld (SARA:SV) Version 2 Användarmanual. Landstinget Västernorrland. Rättspsykiatriska regionkliniken.

Lindgren, M. och Strandell, P. (2010) Våld mot kvinnor. Om polisiära hot- och riskbedömningar. Rapport 2010:2. [Stockholm]: Stiftelsen Tryggare Sverige.

Mellgren et al. (2012) Riskanalys i polisverksamhet. Utvärdering av polisens arbete med riskanalys för våld på individnivå: Skånemodellen och Check $10(+)$. FOU-Rapport 2012:2

Kripo. (2013) Nasjonal drapsoversikt. Tillgängligt elektroniskt på: https://www.politi.no/vedlegg/lokale_vedlegg/kripos/Vedlegg_2398.pdf (senast hämtad 28.3.2014).

Nøttestad, J. A. och Lynum, C. (2012). "Pilotprosjekt for forbygging av vold. Prosjekt SARA:SV." [Oslo]: Politidirektoratet.

Oikeuspoliittinen tutkimuslaitos, henkirikollisuuden seurantajärjestelmä 11.2.2014

Oslo Politidistrikt [2012]: SARA. Et pilotprosjekt ved Stovner politistasjon om risikovurdering og forebyggende tiltak ved partnervold. [Oslo]: Oslo Politidistrikt. Tillgänglig elektroniskt på: https://www.politi.no/vedlegg/lokale_vedlegg/ politidirektoratet/Vedlegg_1909.pdf (senast hämtad 19.12.2013).

Piispa, M., Tuominen, M. och Ewalds, H. (2012) MARAK - kokemuksia parisuhdeväkivallan riskinarvioinnin menetelmän kokeilusta Suomessa (Rapporteja 10/2012). Helsinki: Terveyden ja hyvinvoinnin laitos. 
Politidirektoratet. [2012] Rapport. Risikovurdering - SARA:SV. Pilotsprosjekt 20112012. Vestfold politidistrikt/Horten politistasjon. [Oslo]: Politidirektoratet.

Rikspolisstyrelsen (2010a). Riktlinjer för polisiära riskanalyser vid våld på individnivå. Dnr: POA-400-1222/09. Stockholm: Rikspolisstyrelsen.

Rikspolisstyrelsen (2010b). Inspektion av polismyndigheternas hantering av rutiner vid bl.a. riskanalyser. Inspektionsrapport 2010:8. Stockholm: Rikspolisstyrelsen.

Rikspolisstyrelsen (2012) Inspektion av polismyndigheternas hantering av det lokala personsäkerhets arbetet. Inspektionsrapport 2012:8. Stockholm: Rikspolisstyrelsen.

Robinson, A. (2003) The Cardiff Women's Safety Unit: A Multi-Agency Approach to Domestic Violence. Final Evaluation Report. [S.l.] : School of Social Sciences, Cardiff University. Tillgänglig elektroniskt på www.cardiff.ac.uk/socsi/resources/ robinson-WSU-final-evaluation-report.pdf (senast hämtad 7.12.2013).

Socialstyrelsen. (2012) Manual för FREDA - standardiserade bedömningsmetoder för socialtjänstens arbete mot våld i nära relationer (preliminär version). Stockholm: Socialstyrelsen.

Steel, N, Blakeborough L., och Nicholas, S. (2011) Supporting high-risk victims of domestic violence: a review of Multi-Agency Risk Assessment Conferences (MARACs). Research Report; 55. Tillgänglig elektroniskt på http://www.homeoffice.gov.uk/publications/science-research-statistics/researchstatistics/crime-research/horr55/ (senast hämtad 13.12.2013).

Svensson, K. och Persson, A. (2011) Personutredningar. Organisation, profession och (risk)bedömning. Lund: Kriminalvården.

Westlund, O. (2010). Strukturerad riskanalys vid våld mot närstående. En lägesbeskrivning av polisens arbete. BRÅ- rapport 2010: 20. Stockholm: Brottsförebyggande rådet.

Westfelt, L. (2012). Dödligt våld. I rapporten Brottsutvecklingen i Sverige 20082011. BRÅ- rapport 2012: 13. Stockholm: Brottsförebyggande rådet. 


\section{Summary}

\subsection{Introduction and background}

More than 50 women are killed due to domestic violence in the Nordic countries each year. The situation is most alarming in Finland, where 21 women are killed by a man they are in or have had a close relationship with. The corresponding number for men is substantially lower, although every case is always one too much.

Statistics show that intimate partner violence is a serious and actual problem in the Nordic countries. Can it be effectively prevented, i.e. by the use of different tools for risk assessment? To what degree are these instruments used, and how can the Nordic countries learn from each other?

The first Nordic network between authorities working with violence in close relationships was established during the Finnish presidency of the Nordic Council of Ministers in 2011. A Nordic project within this network has been searching for answers to the questions above.

The results of this project, coordinated by the National Institute for Health and Welfare in Finland, are presented in this report. The report reviews the Nordic authorities' use and experiences of structured professional tools for risk assessment of domestic violence.

\subsection{Targets}

The report aims at furthering the authorities' competence in assessing risks, preventing repeated violence and improving the victims' safety. The results facilitate comparisons between the countries and enable a mutual exchange of knowledge.

The report is mainly based on material from authorities and other bodies. It paints a picture of the current situation and the need for development. Focus lies on risk assessment linked to serious cases of domestic violence, especially violence with a possible lethal outcome.

The report targets politicians, authorities and persons within the public sector and voluntary organizations working with victims and perpetrators of domestic violence. 
Risk assessment is examined based on these central questions: To what degree do authorities use tools for risk assessment? What have the results been and what challenges have emerged?

An important conclusion is that the Nordic authorities' (e.g. social services, police, healthcare) use of risk assessment tools vary greatly. The experiences are nevertheless good, which motivates a continued development of risk assessment work (more conclusions and challenges at the end of this summary).

\subsection{Risk assessment}

Risk assessment work is demanding and there is a great deal at stake - it can be a question of life or death. The objective when dealing with perpetrators is to prevent a recurrence. The goal when in contact with victims is to prevent continued subjection to violence and improve the safety of the victim.

The aim of risk assessment is to outline the threat of violence and to estimate the seriousness of the threat and the possible consequences. Assessment is based on structured and standardized questions. Focus lies on qualitative prediction rather than the mechanical adding of points.

The main goal for risk assessment on the individual level is to prevent, not just predict, a possible act of violence. Based on the results, measures can and should be taken to minimize the risk of violence.

\subsection{Tools for assessment}

Structured and professional instruments for assessing the risk of domestic violence can be divided into two categories: tools used in contact with possible perpetrators and tools used in contact with victims of violence.

The core of the tools consists of practical checklists for e.g. alcohol and substance abuse, depression and suicidal behavior, criminal records and restraining orders.

The following scientific tools are used in the Nordic countries: SARA (Spousal Assault Risk Assessment), the simplified Nordic version SARA:SV (Short Version) and MARAC (Multi-Agency Risk Assessment Conference).

SARA:SV is supplemented by SAM (Stalking Assessment and Management) and Patriark for assessing risk of violence in the name of honor.

SARA and SARA:SV are primarily used for assessing a person's likelihood of repeated episodes of violence. MARAC, or in Finland MARAK 
(moniammatillinen riskinarvioinnin kokous), is used to assess a person's risk of being subjected to violence. High risk cases are, with the client's consent, put forward to a multi-professional MARAK working group.

\subsection{Use in the Nordic countries}

Risk assessment is a natural part of the work within authorities with domestic violence. However, the report shows that use of risk assessment tools varies greatly between authorities and the Nordic countries.

Police and penal authorities in Sweden have guidelines for the use of SARA and SARA:SV. Norway is planning on implementing SARA:SV in all police districts whilst the implementation of the same tool is in its initial stage in Denmark.

Finland does not use the tools mentioned above, but has instead implemented the MARAK model following a successful pilot project (2010-2011).

\subsection{Nordic experiences}

Sweden is the Nordic country with the most experience of using the risk assessment tool SARA. It is extensive and requires clinical knowledge from the user. The tool has been perceived difficult to manage by the police authorities, both in length and set-up. B-SAFER has therefore been developed into SARA:SV to better meet Nordic needs.

In order for risk assessment to be effective it is important to have a clear perspective for organizing the activities and the working process. Experience indicates that there are shortcomings in precisely these matters within many police authorities.

However, SARA:SV has had many positive effects. Subjection to violence has become more visible and high risk cases more tangible. It has created better routines for the police internally, furthered cooperation with other bodies and lead to sustainability in the work process.

The summary of the MARAK project in Finland underlines that cooperation is the starting-point for the method. It is also important to make the working process into a routine and well-structured.

The method has given the involved bodies a better overall view of the victims' situation. The victims are also able to see their own situation more clearly. In addition, information flow and cooperation between different parties has improved. 
MARAK was seen as an effective tool for evaluating threats even if the matter didn't result in an actual MARAK process.

The positive experiences of the pilot project have resulted in a decision to implement the MARAK model throughout country. This work is led by the National Institute for Health and Welfare.

\subsection{Conclusions and challenges}

Many Nordic authorities meet victims and perpetrators in their everyday work. However, it is very demanding to evaluate the risk of violence. It is even more difficult to take effective measures without a clear and comprehensive understanding of the victims' situation.

If violence is identified and the extent of violence is estimated, then measures can be adopted to protect the victims. For a risk assessment process to be initiated it is crucial that authorities are able to identify the risk of violence in the first place.

The report shows that Nordic authorities use tools for risk assessment in highly varying degrees. The overall results are positive where these tools have been implemented.

The instruments improve risk assessment and facilitate communication and cooperation between authorities as well as with other actors. To ensure effective results the process needs to be organized systematically and be thoroughly anchored in all activities.

The use of assessment tools should be backed up by continuous education and vocational training. Cooperation with various actors should be clear and well worked out for everyone involved, and the results must be continuously followed up on.

This equates to distinct routines and a clear distribution of responsibilities, from the initial assessment or routine question about violence to actual safety measures.

Effective risk assessment also requires a sufficient set of services, including services due to special needs (e.g. language, addictions, functional disability, mental illnesses).

The report also concludes that the Nordic network meets the demand for exchange of experience and information in the Nordic countries - the needs for development are the same. The Nordic network is therefore a useful forum for continued development in this area. 


\section{Yhteenveto}

\subsection{Johdanto ja tausta}

Yli 50 naista kuolee vuosittain parisuhdeväkivallan seurauksena Pohjoismaissa. Tilanne on vakavin Suomessa, missä keskimäärin 21 naista saa surmansa joka vuosi parisuhdeväkivallan vuoksi. Tekijä on mies, jonka kanssa nainen on tai on ollut pari- tai seurustelusuhteessa. Vastaava luku miesten osalta on huomattavasti pienempi. Jokainen kuolemantapaus on kuitenkin liikaa.

Tilastojen valossa parisuhteessa tapahtuva väkivalta on todellinen ja vakava ongelma Pohjolassa. Onko tämän kaltainen väkivalta ehkäistävissä esimerkiksi riskinarviointiin perustuvien menetelmien avulla? Kuinka laajalti nämä menetelmät ovat käytössä, ja mitä Pohjoismaat voivat oppia toisiltaan?

Ensimmäinen pohjoismainen verkosto parisuhdeväkivallan kanssa työskentelevien viranomaisten kesken perustettiin vuonna 2011, kun Suomi oli Pohjoismaiden ministerineuvoston puheenjohtaja. Verkostoon kytketty yhteispohjoismainen projekti on etsinyt vastauksia yllä oleviin kysymyksiin.

Raportissa esitetään Terveyden ja hyvinvoinnin laitoksen THL:n koordinoiman projektin tulokset. Raportti käsittelee ammattimaisia menetelmiä, joita pohjoismaiset viranomaiset käyttävät parisuhdeväkivallan riskinarviointiin. Lisäksi raportti pureutuu menetelmistä saatuihin kokemuksiin.

\subsection{Projektin tavoitteet}

Raportin tavoitteena on, että viranomaiset oppisivat arvioimaan parisuhdeväkivallan riskejä, estämään toistuvan väkivallan ja suojaamaan uhreja aiempaa paremmin. Tulokset edesauttavat maiden välisiä vertailuja ja mahdollistavat tiedonvaihdon.

Raportti perustuu lähinnä viranomaisten ja erilaisten elinten materiaaliin, ja se antaa yleiskatsauksen nykytilanteesta ja olemassa olevista kehitystarpeista. Raportti keskittyy riskinarviointityöhön vakavissa parisuhdeväkivaltatapauksissa, varsinkin jos niihin liittyy kuolemanriski. 
Raportin kohderyhmiä ovat poliitikot, viranomaiset ja julkisen sektorin henkilöt sekä vapaaehtoisjärjestöt, jotka ovat tekemisissä parisuhdeväkivallan uhrien ja tekijöiden kanssa.

Raportti tarkastelee riskinarviointia seuraavien keskeisten kysymyksen avulla: missä määrin viranomaiset ylipäätään käyttävät riskinarvioinnin eri menetelmiä, minkälaisia tuloksia niistä on saatu ja mitkä ovat haasteet tulevaisuutta ajatellen.

Tärkeä päätelmä on se, että pohjoismaiset viranomaiset (esimerkiksi sosiaalihuolto, poliisi ja terveyden- ja sairaanhoito) käyttävät kyseisiä menetelmiä hyvin vaihtelevasti. Kokemukset ovat kuitenkin hyvät, ja tämän takia riskinarviointityötä pitäisi kehittää. (Lue lisää päätelmistä ja haasteista yhteenvedon lopusta.)

\subsection{Riskinarviointi}

Riskinarviointityö on vaativaa, ja paljon on pelissä - kyseessä voi olla joko elämä tai kuolema. Väkivaltaan taipuvaista yritetään estää uusimasta tekojaan. Väkivallalle altista taas pyritään auttamaan, jotta hänen turvallisuutensa parantuisi eikä väkivalta uusiutuisi.

Riskinarvioinnissa kartoitetaan väkivaltariski ja arvioidaan sen vakavuus ja mahdolliset seuraukset. Arvioinnit perustuvat standardisoituihin kysymyksiin. Menetelmät keskittyvät laadulliseen arviointiin mekaanisen pistelaskun sijasta.

Riskinarvioinnin tavoitteena yksilötasolla on estää, ei pelkästään ennakoida, mahdollinen väkivallanteko. Arvioinnin tulosten perusteella toimenpiteisiin voi ja täytyy ryhtyä väkivaltariskin minimoimiseksi.

\subsection{Riskinarvioinnin menetelmät}

Menetelmät parisuhdeväkivallan arvioimiseksi voidaan jakaa kahteen ryhmään: väkivallan uhrien kanssa käytettäviin ja väkivaltaan taipuvaisten kanssa käytettäviin.

Menetelmien ydin perustuu lomakkeisiin, joissa selvitetään esimerkiksi alkoholin- ja huumeidenkäyttö ja kysytään masennukseen, itsemurhaajatuksiin, rikosrekisteriin ja lähestymiskieltoihin liittyvistä asioista.

Pohjoismaissa ovat käytössä seuraavat tieteelliset menetelmät: SARA (Spousal Assault Risk Assessment) ja sen lyhennetty pohjoismainen versio SARA:SV (Short Version) sekä MARAC (Multi-Agency Risk Assessment Conference). 
SARA:SV täydentyy stalkkaukseen keskittyvällä SAM-arvioinnilla (Stalking Assessment and Management) ja kunniaväkivaltaan keskittyneellä Patriarkilla.

SARA- ja SARA:SV-menetelmiä käytetään ensikädessä arvioimaan henkilön taipuvaisuutta väkivaltaan. MARAC, Suomessa MARAK (moniammatillinen riskinarvioinnin kokous), puolestaan arvioi henkilön alttiutta väkivallalle. Korkean riskin tapaukset siirretään asiakkaiden suostumuksella moniammatillisen MARAK-työryhmän käsiteltäväksi.

\subsection{Käyttö Pohjoismaissa}

Monille pohjoismaisille viranomaisille riskinarviointi on luonteva osa parisuhdeväkivaltaan liittyvää työtä. Raportin mukaan menetelmien käyttö vaihtelee kuitenkin suuresti eri maiden ja eri viranomaisten välillä.

Ruotsin poliisilla ja kriminaalihuollolla on ohjeet SARA:n ja SARA:SV:n suhteen. Norja suunnittelee SARA:SV:n toimeenpanemista kaikissa poliisipiireissä. Tanskassa SARA:SV:n toimeenpaneminen on alustavassa vaiheessa.

Suomi ei ole ottanut käyttöön näitä menetelmiä. Sen sijaan MARAK on otettu käyttöön menestyksekkään pilottiprojektin (2010-2011) rohkaisemana.

\subsection{Kokemukset Pohjoismaissa}

Ruotsilla on Pohjoismaista pisin kokemus riskinarviointimenetelmä SARA:n käytöstä. Menetelmä on kuitenkin suhteellisen laaja, ja se vaatii käyttäjältään kliinistä osaamista. Poliisin keskuudessa SARA on koettu hankalaksi pituutensa ja muotonsa vuoksi.

SARA:sta on tämän takia kehitetty SARA:SV-malli, joka vastaa paremmin Pohjoismaiden tarpeita. Riskinarviointityön tuloksellisuuden varmistamiseksi on tärkeää nähdä kokonaiskuva toiminnan organisoimisesta ja työprosessin suunnittelusta. Kokemusten mukaan monilla poliisiviranomaisella on puutteita nimenomaan näihin asioihin liittyen.

SARA:SV-menetelmällä on kuitenkin monia myönteisiä vaikutuksia. Väkivalta-alttius huomataan entistä paremmin ja korkean riskin tapaukset on tullut aiempaa enemmän näkyväksi. Riskinarviointi on parantanut poliisin sisäisiä rutiineja, edistänyt yhteistyötä elinten välillä ja antanut työlle enemmän pitkäjänteisyyttä. 
MARAK-pilottiprojektin johtopäätöksissä todetaan, että metodin lähtökohta on yhteistyö. On tärkeää tehdä työstä rutiininomaista ja rakenteellisesti selkeää.

Menetelmä on auttanut mukana olevia tahoja luomaan paremman kokonaiskuvan uhrin tilanteesta, auttanut uhria näkemään asemansa selkeämmin ja parantanut yhteistyötä eri tahojen välillä.

MARAK on koettu tehokkaaksi työvälineeksi riskien ja uhkien kartoittamiseksi myös silloin, kun asia ei ole edennyt MARAK-käsittelyyn.

Pilottiprojektista saadut hyvät kokemukset ovat johtaneet siihen, että MARAK-mallia levitetään koko maahan. Projektia johtaa Terveyden ja hyvinvoinnin laitos.

\subsection{Päätelmät ja haasteet}

Useat pohjoismaiset viranomaiset kohtaavat väkivallan uhreja tai väkivallan tekijöitä. Väkivaltariskin arvioiminen on hyvin haastavaa, ja vielä vaikeampaa on tarttua asiaan tehokkaasti ilman selkeää kokonaiskuvaa väkivallan uhrin tilanteesta. Jos väkivalta tunnistetaan ja laajuus arvioidaan, viranomaiset voivat ryhtyä toimenpiteisiin uhrin suojelemiseksi. Jotta riskinarvioinnin prosessi ylipäätään pääsisi käyntiin, viranomaisilla täytyy olla valmius tunnistaa väkivaltariskin olemassaolo. Raportin mukaan pohjoismaiset viranomaiset käyttävät riskinarvioinnin välineitä hyvin vaihtelevasti. Menetelmiä käyttäneiden viranomaisten kokemukset ovat kuitenkin yleisesti hyvät.

Menetelmät parantavat riskinarviointia ja helpottavat viestintää ja yhteistyötä viranomaisten ja muiden tahojen välillä. Jotta välineiden käyttö olisi mahdollisimman tehokasta, työn täytyy olla systemaattista ja luonteva osa toimintaa.

Riskinarviointimenetelmien käyttöä täytyy jatkuvasti tukea esimerkiksi koulutuksella ja jatkokoulutuksella. Eri tahojen yhteistyön pitää toimia ja olla selkeää kaikille osapuolille, ja tuloksia pitää seurata.

Työprosessin kannalta tämä tarkoittaa selkeitä rutiineja ja selvää vastuunjakoa, aina varhaisesta arvioinnista tai rutiinikysymyksistä suojelutoimenpiteisiin asti.

Tehokas riskinarviointi edellyttää myös riittävästi palveluita. Erityispalveluita täytyy olla saatavilla niille, jotka sellaisia tarvitsevat vaikkapa kielen, vamman tai psyykkisen sairauden vuoksi.

Pohjoismainen verkosto on hyvä foorumi kokemusten ja tiedonvaihtoon, koska kehitystarpeet ovat kaikille yhteiset. 


\section{Bilaga}

\subsection{Bilaga 1: Våldsstatistik}

I tabellerna 1-4 uppges antal kvinnor som blivit dödade av en man de har haft eller har en nära relation till (gift/sambo, ex-partner) respektive antal män som bragts om livet av en kvinna de har haft eller har en nära relation till. Uppföljningsperioden är kortare för Danmarks del och där saknas också uppgifter gällande män.

Tabell 1. Antal fall av dödligt våld mot kvinnor och män i nära relationer $i$ Finland. (Oikeuspoliittinen tutkimuslaitos, henkirikollisuuden seurantajärjestelmä 11.2.2014)

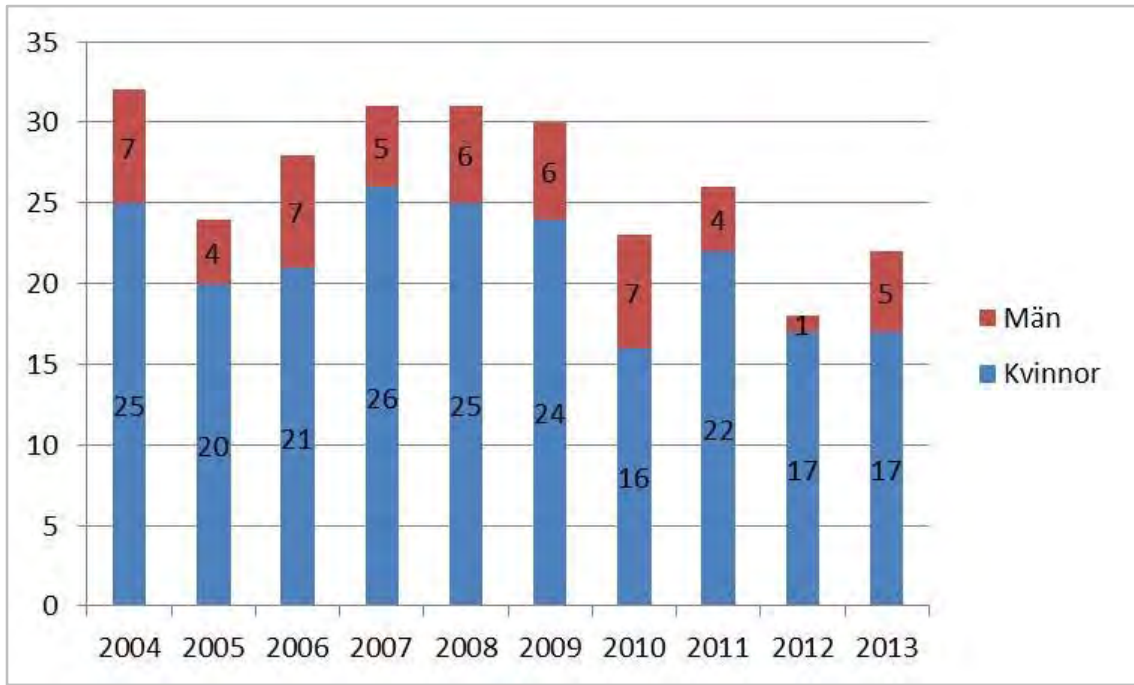


Tabell 2. Antal fall av dödligt våld mot kvinnor och män i nära relationer i Norge (Nasjonal drapsoversikt 2013. Kripo)

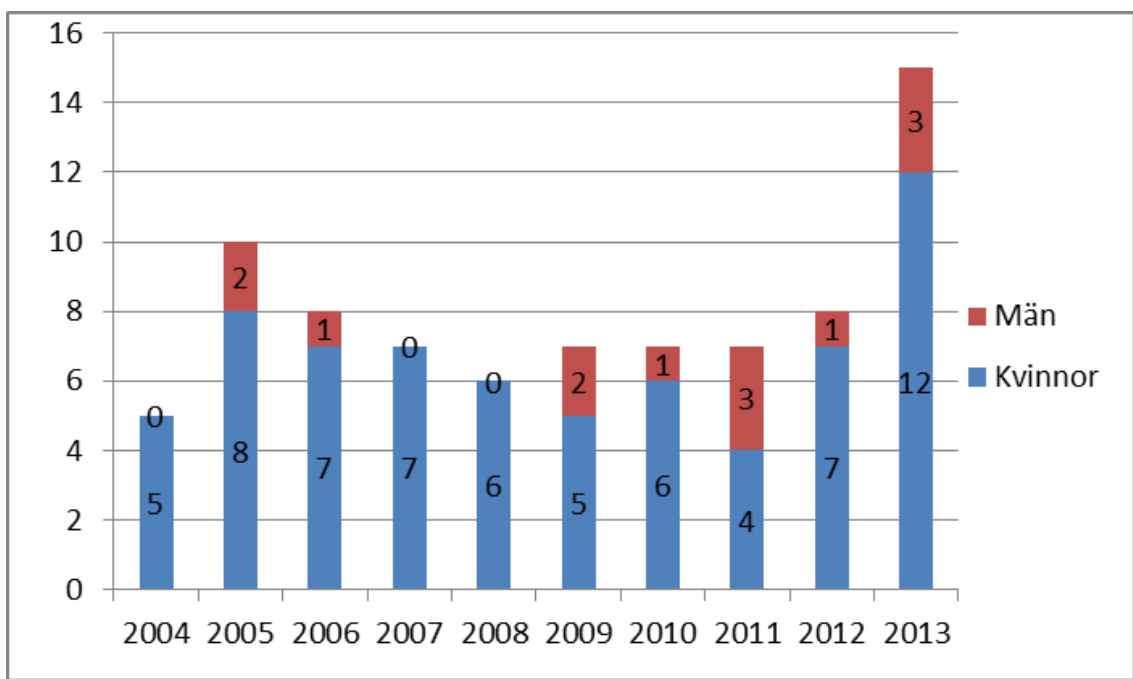

Tabell 3. Antal fall av dödligt våld mot kvinnor och män i nära relationer på Island. (Jensson Jóhannes. Opublicerad statistik från polisen på Island. 24.2.2014.)

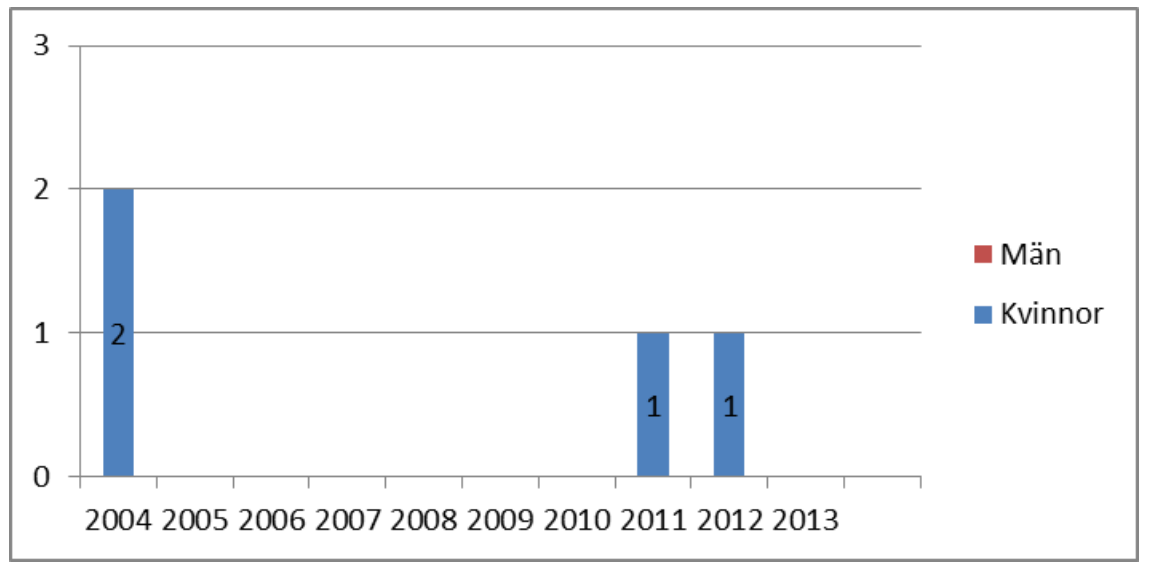


Tabell 4. Antal fall av dödligt våld mot kvinnor i nära relationer i Danmark (Justitsministeriets Forskningskontor. Drab i Danmark 2008-2011. 2014)

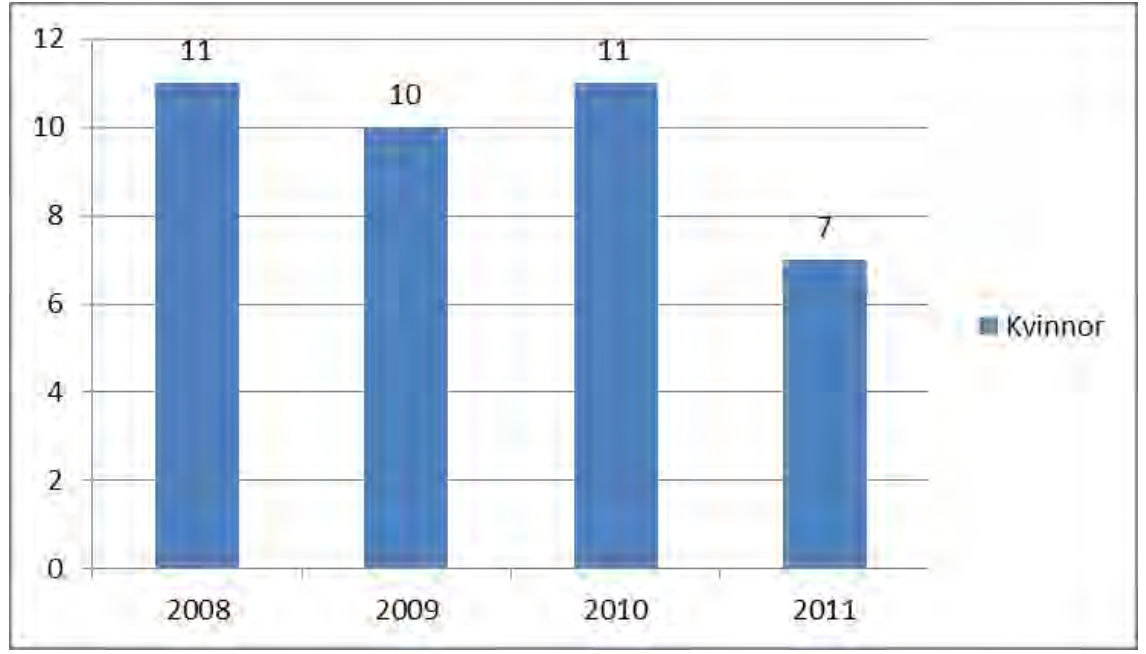

\subsection{Bilaga 2: MARAK (Moniammatillinen riksinarvioinnin kokous)}

I Finland används förkortningen MARAK (moniammatillinen riskinarvioinnin kokous) för den multiprofessionell riskbedömningssamverkan där bl.a. polis, socialvård, hälso- och sjukvård samt frivilligorganisationer ingår. Modellen är hämtad från Storbritannien. De material som används i modellen är riskbedömningsformuläret och en manual samt en blankett där klienten ger sitt samtycke att ärendet hänvisas till en MARAK arbetsgrupp.

Riskbedömningen fastställs i samtal med den våldsutsatta utifrån det standardiserade frågeformuläret. Offrets behov av skydd analyseras av multiprofessionella team, som enas om skyddsåtgärder för att förhindra att personen utsätts för våld på nytt.

\subsubsection{Standardiserade frågor}

Den standardiserade riskbedömningsblanketten, som ligger till grund för samtalet med den våldsutsatta, består av 24 frågor kring riskfaktorer. Till dessa hör faktorer som i forskningsresultat visats sig vara kopplade till en förhöjd risk att utsättas för våld. I instruktionerna ingår kunskap om dessa faktorer, för att bedömaren skall känna till och förstå de mekanismer och konsekvenser som är sammanknippade med våld. Frågorna är riktade till den våldsutsatta, men information också från 
andra källor kan inkluderas. Våldet kan utföras av en eller flera förövare, varför bedömaren tidigt under samtalet bör klargöra vem eller vilka personer som utredningen omfattar. Hedersrelaterad problematik uppmärksammas. Riskbedömningen kan göras av vilken som helst av de myndigheter som den våldsutsatta kommer i kontakt med.

I manualen finns instruktioner för riskbedömningen. Av dem framgår syftet med formuläret och vad intervjuaren bör hålla i minnet inför samtalet med våldsoffret. Bland annat nämns vikten av att tala i enrum under trygga former, utreda var våldsutövaren och eventuella barn befinner sig och berätta hur den erhållna informationen kommer att hanteras i MARAK.

\subsubsection{Bedömning}

Efter intervjun med våldsoffret bör bedömaren ta ställning till övriga fakta såsom relevant information om våldsutövaren, huruvida det behövs akuta skyddsåtgärder, risken för att eventuella barn utsätts för våld och huruvida en barnskyddsanmälan gjorts samt våldsoffrets allmäntillstånd och beredskap att vidta de överenskomna åtgärderna. Slutligen tar bedömaren ställning till om det finns skäl att föra ärendet till en MARAK arbetsgrupp. Denna bedömning görs på basis av följande kriterier:

- Våldsoffret har gett 14 eller flera ja-svar på frågorna som ingår i riskbedömningsinstrumentet. Observera att färre poäng INTE utesluter en MARAK-behandling av ärendet.

- Bedömarens helhetsbedömning för att risken för våld är hög.

- Polisen har under de senaste 12 månaderna gjort åtminstone tre utryckningar till familjen.

\subsubsection{Stödperson}

Om risken bedöms vara hög för att offret upprepade gånger utsättas för våld och offret ifråga ger sitt samtycke till att ärendet behandlas i MARAK, utses en stödperson. Stödpersonens uppgift är att vara i aktiv kontakt med våldsoffret, stöda henne i praktiska ärenden och delge MARAK-gruppen klientens synpunkter och önskemål gällande den säkerhetsplan som uppgör. Därtill bör stödpersonen, motivera våldsoffret att följa säkerhetsplanen och erbjuda stöd under hela processen. Som stödpersoner fungerar frivilligorganisationers MARAK-utbildade personer. 


\subsubsection{MARAK-behandling}

MARAK-behandlingen är m.a.o. ett multiprofessionellt möte, där deltagarna utbyter information och kommer överens om åtgärder. Deltagarna kommer ofta från t.ex. polisen, brottsofferjouren, barnomsorgen, hälsooch sjukvården och socialvården. Möten ordnas regelbundet. Till deltagarnas uppgifter hör även att förbereda sig inför mötena genom att sammanställa den befintliga dokumentation om fallet som den egna organisationen innehar. Vid mötet ger den organisation som sammanställt riskbedömningen en kort presentation av ärendet. Därefter diskuteras möjliga förslag på åtgärder. En säkerhetsplan görs upp för den våldsutsatta och för vem som ansvarar för vad dokumenteras. Våldsoffret deltar i regel inte i mötena, vilket dock hennes stödperson gör. Den som gjort riskbedömningen är vanligtvis också den som tar kontakt med våldsoffret. I de fall riskbedömningen gjorts av polisen är det dock polisens socialarbetare som tar kontakt. Också stödpersonen informerar klienten om stödåtgärderna. Säkerhetsplanen dokumenteras i sin helhet och utgör underlag för den kommande uppföljningen.

\section{MARAK-arbetsprocessen består av åtta faser}

1. Våld identifieras och klienten informeras om MARAK och riskbedömning.

2. Risbedömningen görs.

3. Vid hög risk sänds ärendet vidare till MARAK-behandling, förutsatt att klienten gett sitt samtycke. En stödperson utses.

4. De deltagande organisationerna sammanställer den information de har om fallet.

5. Vid MARAK-möten följs tidigare fall upp och nya introduceras.

6. En säkerhetsplan görs för varje fall. Mötesdeltagarna gör sina respektive åtgärdsförslag och dokumenterar de åtgärder som den egna organisationen ansvarar för.

7. Överenskomna åtgärder vidtas och klienten delges information om beslutet.

8. Fallet följs upp. Om våld förekommit på nytt sänds ärendet tillbaka till MARAK-arbetsgruppen. 


\begin{tabular}{|c|c|c|c|c|}
\hline Offrets namn: & Diari & numme & & \\
\hline 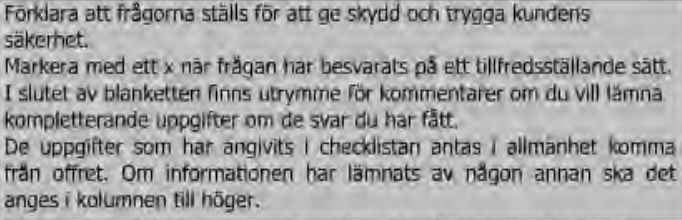 & Ja & Nej & $\begin{array}{l}\text { Vet } \\
\text { ej }\end{array}$ & Kommentarer \\
\hline $\begin{array}{l}\text { 1. Har det văldsbrott som nu ăr under behandling orsakat skador? } \\
\text { (Hurdana skador? Ar det forsta gången som offret har fătt skador?) }\end{array}$ & $\square$ & $\square$ & $\square$ & \\
\hline 2. Är đu văldigt rădd? & $\square$ & $\square$ & $\square$ & \\
\hline $\begin{array}{l}\text { 3. Vad är du rädd for? Ar du radd for nya skador eller mera våld? } \\
\text { Berätta vad du tror att (namnet på văldsutövaren/văldsutovarna...) } \\
\text { gộr och gentemot vem, inklusive barnen. }\end{array}$ & $\square$ & $\square$ & $\square$ & \\
\hline 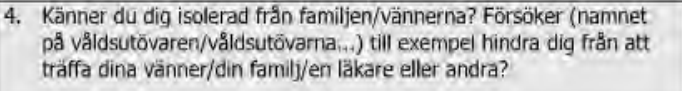 & $\square$ & Q & $\square$ & \\
\hline 5. Ar du deprimerad eller har du sjalvmordstankar? & $\square$ & $\square$ & $\square$ & \\
\hline $\begin{array}{l}\text { 6. Har du skilt dig eller försökt flytta isâr frăn (naminet pŭ } \\
\text { văldsutövaren/validsutövarna....) under det senaste ăret? }\end{array}$ & $\square$ & $\square$ & $\square$ & \\
\hline 7. Har ni gräl när det gäller kontakten med barnen? & $\square$ & $\square$ & $\square$ & \\
\hline $\begin{array}{l}\text { 8. Sänder (...) ideligen textmeddelanden till dig eller ringer, tar } \\
\text { kontakt, följer efter dig ibland eller systematiskt (stalking) eller är } \\
\text { på annat sätt närgången? (Berätta närmare vad. Tror du att han } \\
\text { gör det avsiktligt för att skrämma dig? Fundera i vilka } \\
\text { sammanhiang det sker och hur (...) beter sig.) }\end{array}$ & $\square$ & Q & $\square$ & \\
\hline $\begin{array}{l}\text { 9. Är du gravid eller har du fött ett barn under de senaste } 18 \\
\text { månaderna? }\end{array}$ & $\square$ & $\square$ & $\square$ & \\
\hline 10. Sker misshandeln oftare nu jämfört med tidigare? & 口 & $\square$ & $\square$ & \\
\hline 11. Har våldet blivit grövre? & $\square$ & $\square$ & $\square$ & \\
\hline $\begin{array}{l}\text { 12. Försöker ( . .) kontrollera allt du gör och/elier àr (...) väldigt } \\
\text { svartsjuk? (Frågor om människorelationer: Vem hăller du kontakt } \\
\text { med? Vaktar ( ...) dig dár hemma och bestammer till exempel vad } \\
\text { du ska ha pä dig? Ta hedersrelaterat väld i beaktande och be om } \\
\text { detaljerade uppgifter om hur (...) beter sig.) }\end{array}$ & $\square$ & $\square$ & $\square$ & \\
\hline $\begin{array}{l}\text { 13. Har (...) någonsin använt vapen eller andra foremål för att skada } \\
\text { dig? }\end{array}$ & $\square$ & $\square$ & $\square$ & \\
\hline
\end{tabular}

Q Web worv.caada org.uk Q CAADA svensksprékig ôversätrning Institutet fôr hälsa och valfärd. 


\begin{tabular}{|c|c|c|c|}
\hline $\begin{array}{l}\text { 14. Har (...) năgonsin hotat att döda dig eller năgon annan să att du } \\
\text { verkligen har trott pă det? } \\
\text { Dig } \square \text { Barnen } \square \text { Năgon annan } \square\end{array}$ & $\square$ & $\square$ & $\square$ \\
\hline 15. Har (...) nágorisin forsökt strvpa/kväva eller drânka dig? & $\square$ & $\square$ & $\square$ \\
\hline 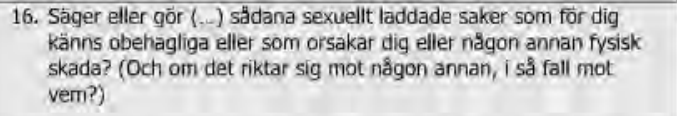 & $\square$ & $\square$ & $\square$ \\
\hline $\begin{array}{l}\text { 17. Har någon annan person hotat dig eller är du raddd for năgon } \\
\text { annán person? (Om svaret àr ja, i så fall vern och varför? Beakta } \\
\text { även hela släkten i samband med hedersrelaterat valld.) }\end{array}$ & $\square$ & $\square$ & $\square$ \\
\hline $\begin{array}{l}\text { 18. Vet du om (.) har varit våldsam mot någon annan? (I sả fall mot } \\
\text { vem, inklusive barn, syskon eller äldre släktingar. Beakta } \\
\text { hedersrelaterat văld,) } \\
\text { Barnen } \square \text { Andra familjemedlemmar } \square \text { F.d. partner } \square \\
\text { Andra, vem? } \square\end{array}$ & $\square$ & $\square$ & $\square$ \\
\hline 19. Har (...) năgonsin använt våld mot djur eller familjens husdjur? & $\square$ & $\square$ & $\square$ \\
\hline $\begin{array}{l}\text { 20. Finns det ekonomiska faktorer } 50 \mathrm{~m} \text { borde beaktas? Till exempel, } \\
\text { ar du ekonomiskt beroende av (..., har du eller (...) nyligen } \\
\text { förlorat din/sin arbetsplats eller har ni andia ekonomiska } \\
\text { bekymmer? }\end{array}$ & $\square$ & $\square$ & $\square$ \\
\hline $\begin{array}{l}\text { 21. Har (..) under det senaste dret haft problem med lakemedel, } \\
\text { droger, alkohol eller den mentala hälsan să att de orsakat, } \\
\text { bekymmer i vardagen? (Om svaret àr ja, ge närmare information.) } \\
\text { Droger/mediciner } \square \text { Alkohol } \square \text { Mental hălsa } \square\end{array}$ & $\square$ & $\square$ & $\square$ \\
\hline 22. Har (..) năgonsin hotat att begă eller försö́kt begå sjalvmord? & $\square$ & $\square$ & $\square$ \\
\hline $\begin{array}{l}\text { 23. Har (..) någonsin brutit mot besöksförbudet, reseforbudet, } \\
\text { villkoren for overvakad frihet på prov eller avtalet om } \\
\text { umgängesrätt med barnen? (Det kan vara bra att aven bedöma } \\
\text { hur misshandlaren har följt dessa i förhällande till sin före detta } \\
\text { partner.) } \\
\text { Besöksförbud } \square \text { Reseförbud } \square \text { övervakad frihet på prov } \square \\
\text { Avtal am umgăngesrätt med barnen } \square \text { Annat } \square\end{array}$ & $\square$ & $\square$ & $\square$ \\
\hline $\begin{array}{l}\text { 24. Vet du om (..) någonsin har haft problem med polisen eller orn } \\
\text { (...) har ett straffregister? (Om svaret är ja, be om närmare } \\
\text { information.) } \\
\text { Partnervald } \square \text { Sexuelt văld } \square \text { Annan typ av văld } \square \\
\text { Annan orsak } \square\end{array}$ & $\square$ & $\square$ & $\square$ \\
\hline var & & & \\
\hline
\end{tabular}

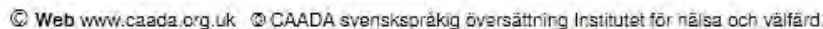


Saker som den professionella frågeställaren bör överväga: Finns det annan information (från offret eller rent yrkesmässigt) med anknytning till ärendet som kan öka risken för våld? Fundera över offrets situation med tanke på toll exempel fysisk funktionsförmåga, missbruk ay rusmedel, mental hälsa, kulturella och språkliga hinder, hedersrelaterad praxis och nedvärderande attityd. Àr offret redo alt ta emot bjälp eller tjănster?

Vilka primära ătgärder krävs för att forbättra offrets säkerhet?

Vad är misshandlarens yrke/hobbyer? Ger de en möjlighet att komma ât vapen?

1. Finns det skäl att lämna detta ärende till ett multiprofessionellt team för riskbedömning (MARAK)? Ja $\square$ Nej $\square \quad$ (se kriterierna för riskbedömningen nedan)

- Din professionella bedömning av situationen: är du allvarligt orolig?

14 eller fler ja-5var

Antalet pollsutryckningar till hemmet p̊̊ grund av familjevåld under de senaste 12 mănadema (tre stycken eller fler)

2. Tror du att det finns risk för vẩld mot familjens barn?

2 Ja $\square$ Har en barnskyddsarimälan gjorts (Barnskyddslagen 25 §)? Ja $\square$ Nej $\square$

Nej $\square /$ Inga barn $\square$

3. Fyll i de samtyckesblanketter som behövs och lämna de till kontaktpersonen för det multiprofessionella teamet.

\section{Namn och yrkesbeteckning: \\ Ämbetsverk/avdelning: \\ Telefonnummer/e-postadress:}

Underskrift och datum: 


\subsection{Bilaga 3: SARA (Spousal Assault Risk Assessment)}

Det kanadensiska bedömningsinstrumentet SARA består av en manual och en checklista för att bedöma risk för upprepade våldshandlingar mot närstående, vilka tagits fram för och av kliniker. Instrumentet är avsett för vuxna förövare (18 år eller över). Användning av instrumentet kräver utbildning.

\subsubsection{Frågorna}

Checklistan består av tjugo frågor som lyfter fram riskfaktorer vilka identifierats i den vetenskapliga litteraturen. Instrumentet är utvecklat för arbete med våldsförövaren eller -förövarna. Frågorna handlar om kriminell bakgrund, tidigare våld, aktuella misstankar om våld, samt psykosocial anpassning. Instrumentet lämnar också utrymme för övriga överväganden.

För varje faktor bedöms huruvida den föreligger eller inte. Faktorerna kan också skattas som "kritiska" vilket innebär att de är särskilt vägande för bedömningen av risk. Manualen betonar att bedömningen inte är en enkel linjär funktion där poäng summeras utan en enda kritisk faktor kan leda till bedömningen hög risk även i frånvaro av andra riskfaktorer.

\subsubsection{Informationsunderlag}

Alla tillgängliga källor ska användas, det kan till exempel röra sig om intervjuer/förhör med gärningsperson respektive våldsutsatta och vittnen, standardiserade mått på fysisk eller psykisk misshandel liksom på substansmissbruk. Dessutom används annan tillgänglig information, ur till exempel belastningsregister och polisrapporter, och övriga psykologiska bedömningsförfaranden. Som stöd för bedömningen finns också en checklista över vilka källor som använts.

\subsubsection{Bedömningen}

Bedömaren summerar bedömningen för att bedöma huruvida 1) det föreligger omedelbar risk för våld mot partner, samt 2) omedelbar risk föreligger för våld mot annan identifierbar person, såsom barn, andra släktingar eller en före detta hustrus eller flickväns nya partner. Risken bedöms på en tregradig skala $1=$ låg, $2=$ måttlig och $3=$ hög risk. 
Risk- och behovsbedömningen med SARA skrivs i löpande text. I texten ska framgå utredningens syfte och sammanhang; underlag; vem som är utsatt för risk; sammanfattning av SARA:s 20 faktorer; omnämnande om vilka faktorer som ökar risken; risknivå (låg, medel, hög); riskens karaktär; tidsperspektiv; samt riskhanteringsförslag. 


\section{Bedömning av risk för framtida partnervåld}

\section{Kriminell bakgrund}

1. Tidigare intrafamiljärt våld

2. Tidigare extrafamiljärt văld

3. Tidigare misskötsamhet vid permission eller liknande

\section{Psykosocial anpassning}

4. Problem i förhållanden under senare tid

5. Problem påa arbetsmarknaden under senare tid

6. Som ung offer for, eller vittne till, våld inom familjen

7. Misabruk eller beroende av alkohol eller droger under senare tid

8. Suicidait eller homicidalt tankeinnehåll, eller avsikt, under senare tid

9. Psykotiska och/eller maniska symptom under senare tid

10. Personlighetsstōming karaktäriserad av aggressivitet, impulsivitet eller instabilitet

\section{Tidigare partnervåld}

11. Tidigare bruk av fysiakt våld

12. Tidigare bruk av gexuellt våld/gexuell gvartsjuka

13. Tidigare anvāndning av vapen och/eller allvarliga dódshot
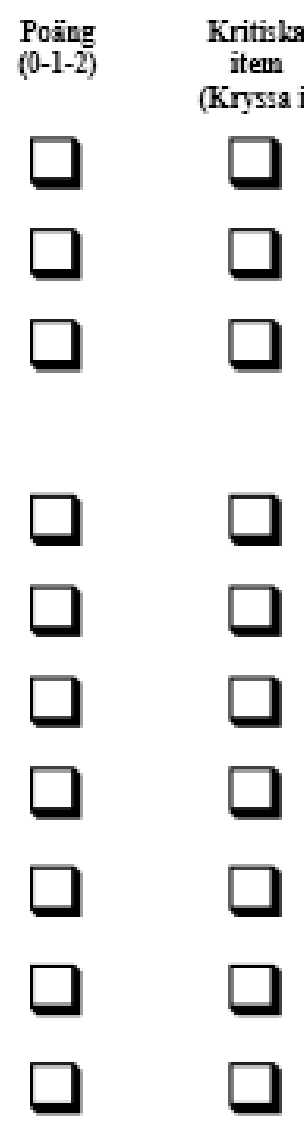

Poāng

$(0-1-2)$

Kritiska item (Kryssa i)

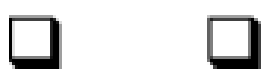

$\square \quad \square$

$\square$ 
14. Upptrappning

15. Tidigare överträdelse av besöksförbud

16. Bagatelligerande eller fömekande av tidigare partnervâld

17. Attityd som stóder eller ursäktar partnervåld

\section{Aktuell brottslighet}

18. Alvarligt sexuellt- eller annat våld

19. Användning av vapen och/eller allvarligt dödshot

20. Ōverträdelse av besöksförbud

\section{Andra överväganden}
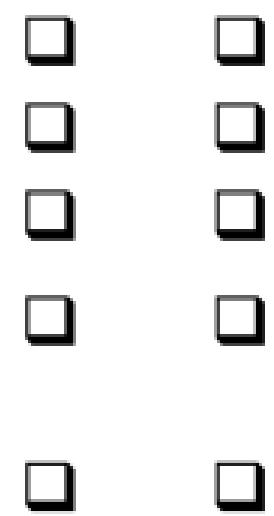

口 $\square$
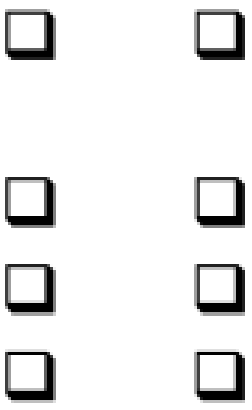

Summering av riskbedömr ingen

1. Overhängande riak för partmervåld
andra

Specificera: 


\subsection{Bilaga 4: SARA:SV (Spousal Assault Risk Assessment: Short Version)}

B-SAFER (Brief Spousal Assault Form for the Evaluation of Risk) är en vidareutveckling av SARA för polisiär användning, i översatt och bearbetad version SARA:SV (Kropp, Hart \& Belfrage 2008, 2011). Instrumentet är avsett för vuxna förövare (18 år eller över). För användare krävs utbildning.

\subsubsection{Frågorna}

Instrumentet omfattar femton frågor, varav fem berör risk hos gärningspersonen, fem beskriver gärningsmannens psykosociala situation, samt fem frågor för att skatta den våldsutsattas sårbarhet. För varje faktor anges huruvida den föreligger eller inte, föreligger delvis, eller information saknas. Det finns också utrymme i checklistan för "övriga överväganden" som inte faller direkt under någon av de färdigt angivna punkterna.

\subsubsection{Informationsunderlag}

Källor för bedömningen är all tillgänglig information, däribland intervjuer/förhör med gärningsperson respektive våldsutsatta och vittnen, standardiserade mått på fysisk eller psykisk misshandel liksom på substansmissbruk, samt övrig tillgänglig information, ur till exempel belastningsregister och polisrapporter, och därtill övriga psykologiska bedömningsförfaranden. Bedömaren redogör i formuläret för vilka källor som nyttjats.

\subsubsection{Bedömningen}

Bedömaren tar ställning till frågor om huruvida det föreligger 1) akut risk respektive 2) risk för mycket allvarligt eller dödligt våld enligt skalan L (låg), M (medel) och $\mathrm{H}$ (hög). I fält för fritt formulerad text specificeras riskens karaktär samt listas föreslagna skyddsåtgärder. 


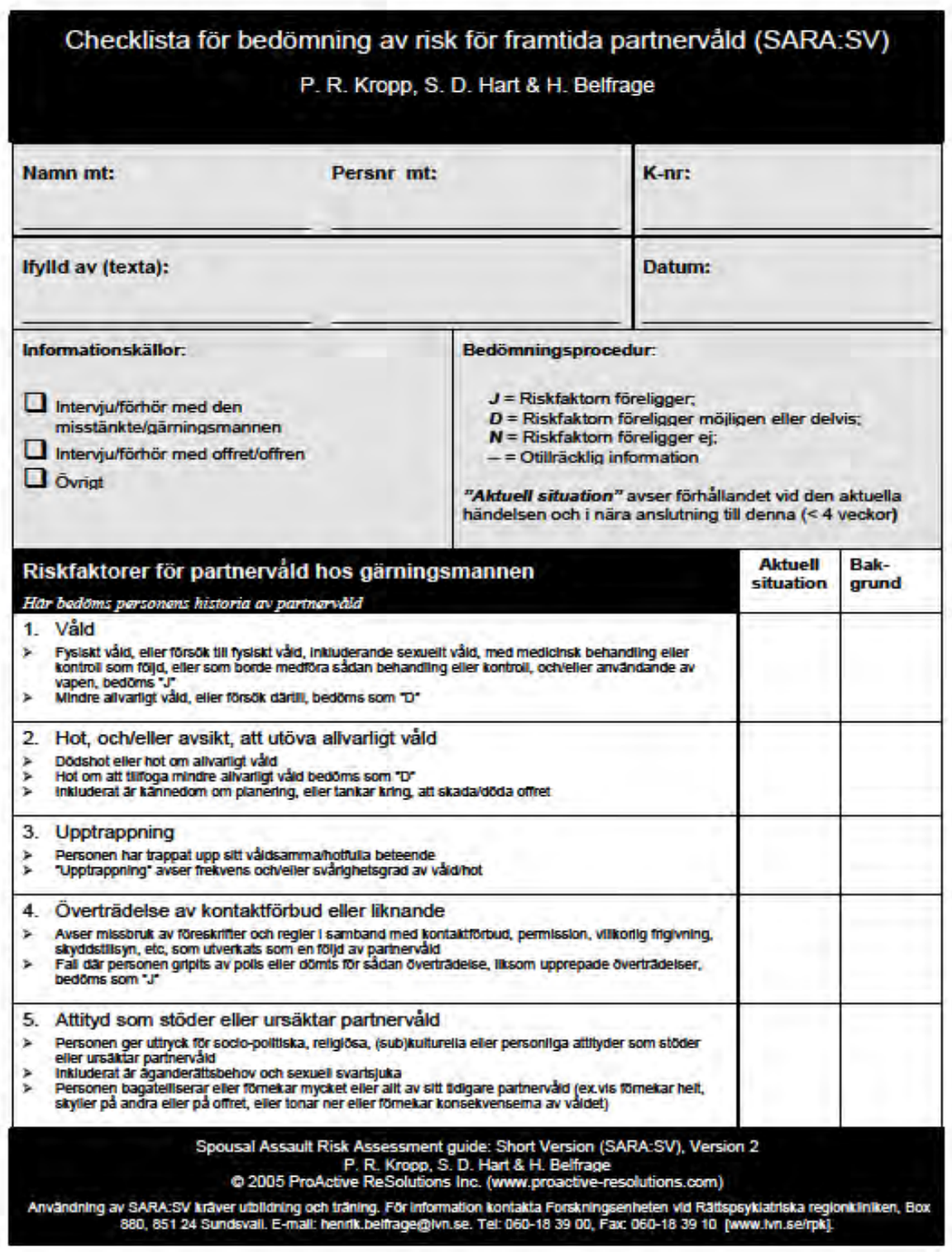




\begin{tabular}{|c|c|c|}
\hline Gärningsmannens psykosociala situation & $\begin{array}{l}\text { Aktuell } \\
\text { situation }\end{array}$ & $\begin{array}{l}\text { Bak- } \\
\text { grund }\end{array}$ \\
\hline 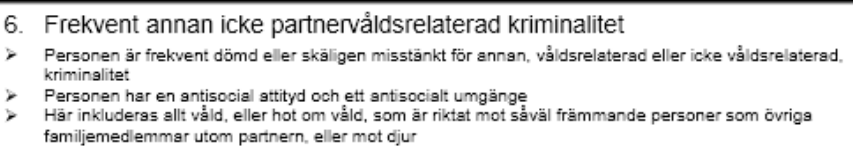 & & \\
\hline $\begin{array}{l}\text { 7. Allvarliga relationella problem } \\
\text { Sepgration från sin partner, och/eller ett eller flera mycket konfikktfyllda förhållanden } \\
\text { Bedömning skall här göras sv omständigheter àven oberoende av den aktuells händelsen }\end{array}$ & & \\
\hline $\begin{array}{l}\text { 8. Problem på arbetsmarknaden/ekonomiska problem } \\
\text { Arbetslöshet, en instabil situation på arbetsmarknaden, eller betydande ekonomiska problem }\end{array}$ & & \\
\hline $\begin{array}{l}\text { 9. Missbruksproblem } \\
\text { "Missbruk" avser att personens missbruk av alkohol eller droger har försämrat dennes hälsotillstảnd } \\
\text { eller sociala förmăga (ex.vis overkonsumtion, omhändertsgen av polis eller uppsagd frấn sitt arbete) }\end{array}$ & & \\
\hline 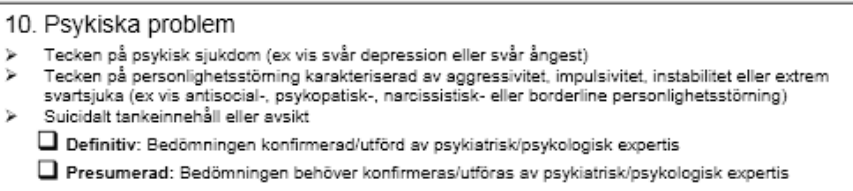 & & \\
\hline $\begin{array}{l}\text { Sårbarhetsfaktorer hos offiret } \\
\text { Här bedöms faktorer hos offret som kan vara av betydelse för skyddsarbetet }\end{array}$ & $\begin{array}{l}\text { Aktuell } \\
\text { situation }\end{array}$ & $\begin{array}{l}\text { Bak- } \\
\text { grund }\end{array}$ \\
\hline $\begin{array}{l}\text { 11. Inkonsekvent beteende eller attityd gentemot gärningsmannen } \\
\text { Offrets uppträdande eller attityd mot gärningsmannen är inkonsekvent, exempelvis återtagande av } \\
\text { anmälan } \\
\text { Hâller ingen "rak linje" i sitt beteende eller sänder "dubbla budskap" } \\
\text { Kontaktar själv gärningsmannen indirekt eller direkt } \\
\text { Normaliserar och minimerar gärningsmannens beteende } \\
\text { Följer inte uppgjorda skyddsplaner }\end{array}$ & & \\
\hline 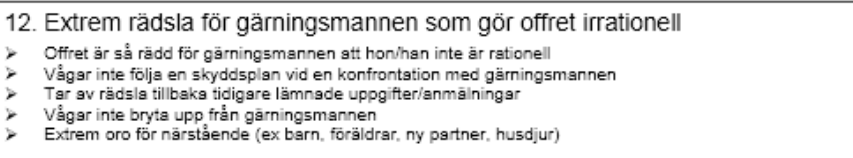 & & \\
\hline 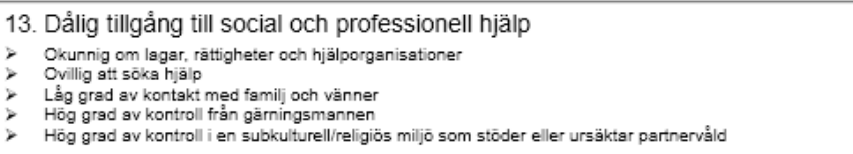 & & \\
\hline 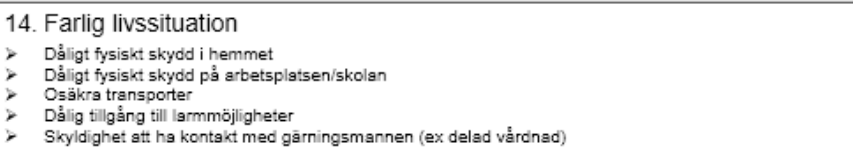 & & \\
\hline 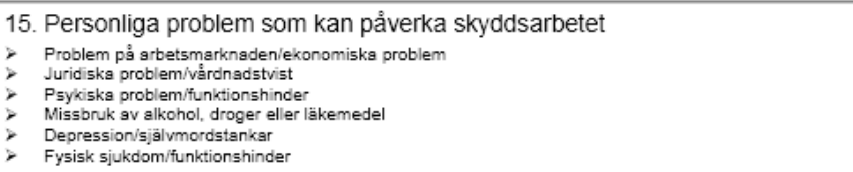 & & \\
\hline
\end{tabular}




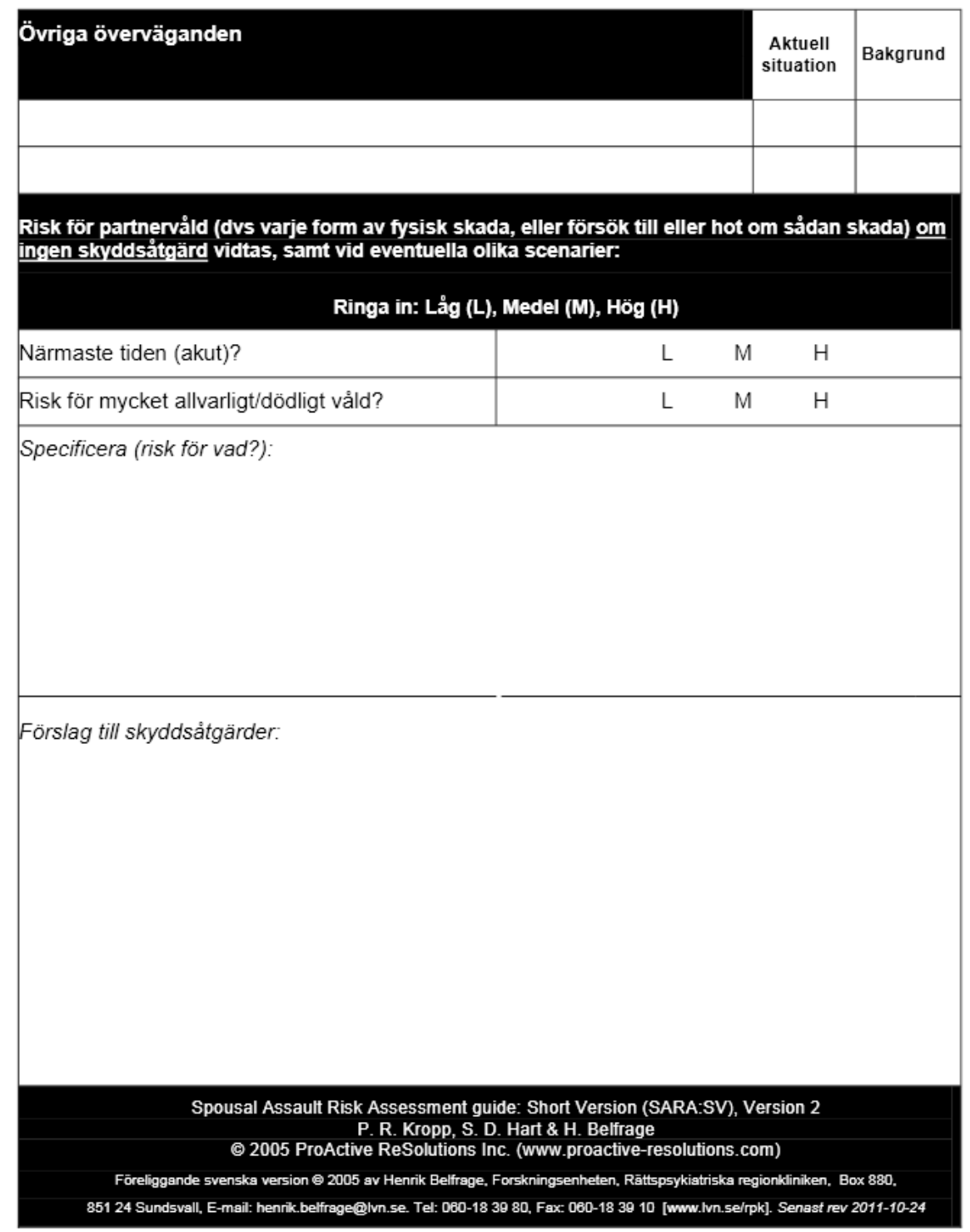




\subsection{Bilaga 5: Beskrivning av omnämnda bedömningsinstrument}

\subsubsection{SAM (Stalking Assessment and Management)}

SAM är ett verktyg för riskbedömning av förövare i ärenden av förföljelse och upprepade trakasserier (stalking). Den kanadensiska forskargruppen bakom SARA står också bakom bedömningsverktyget SAM. SAM utgörs av en checklista som är uppbyggd på liknande sätt med tre avsnitt frågor som karakteriserar fallet. De första frågorna klargör vilka former av stalking fallet gäller, följande uppsättning frågor behandlar riskfaktorer hos gärningsmannen och det sista avsnittet behandlar sårbarhetsfaktorer hos de utsatta (Belfrage och Strand 2007).

\subsubsection{Patriark}

Patriark är ett verktyg för bedömning av risk för hedersrelaterat våld. Checklistan består av två delar, en för riskfaktorer hos förövaren eller förövarna, samt en för sårbarhetsfaktorer hos den eller de hotade. Riskfaktorerna baserar sig både på den vetenskapliga litteraturen kring risk i allmänhet, framför allt från HCR-20, SAM och SARA:SV, och litteratur kring hedersrelaterat våld specifikt (Belfrage 2005). Sårbarhetsfaktorerna är till stor del hämtade från SARA:SV (ibid.)

\subsubsection{Skånemodellen}

Skånemodellen eller -metoden är inget egentligt instrument utan en arbetsprocess vilken används för olika brottstyper (såväl organiserad brottslighet som våld i nära relationer eller hedersrelaterat våld osv). Arbetssättet tar stöd i en manual (Metodstöd för riskanalyser vid våld på individnivå. Taktisk ledning, Gosenius 2013). Bedömningsmetoden är (delvis) strukturerad men är inte utformad som en checklista. Istället har bedömaren som underlag ett öppet frågeformulär med rubriker under vilka information sorteras in av bedömaren och beskrivs i fritext (Mellgren et al. 2012). 


\subsubsection{FREDA-farlighetsbedömning}

Verktyget är ett i en uppsättning av tre instrument för att identifiera våld, kartlägga dess omfattning samt uppskatta risk: 1) FREDAkortfrågor, 2) FREDA-beskrivning och 3) FREDA-farlighetsbedömning (Socialstyrelsen 2012). Målgrupp är våldsutsatta personer. De 20 frågorna i FREDA-farlighetsbedömning berör bland annat förövarens tillgång till vapen, kontrollerande beteende och substansmissbruk hos denne, våldets eventuella eskalering, samt hot mot eventuella barn. Frågorna är riktade i du-form till den våldsutsatta och besvaras med "ja" eller "nej." Bedömningen görs som en sammanräkning av poängen (där ja-svar ger ett eller flera poäng beroende på vad som efterfrågas). Risknivån anges från 1 till 4. Instrumentet är inte vetenskapligt utprövat och har mötts med kritik (se Carlsson 2013).

\subsubsection{HCR-20 (Historical, Clinical, Risk Management-20)}

HCR-20 är ett tredje generationens riskbedömningsinstrument för framtida våld. Målgrupp är lagöverträdare med psykisk ohälsa och bedömare är kliniker. Instrumentet är en klinisk checklista med 20 riskfaktorer vilka identifierats genom forskning. Instrumentet hör till de mest använda internationellt.

\subsubsection{PCL-R (Psychopathy Checklist Revised)}

PCL-R är ett bedömningsinstrument för att mäta psykopati hos vuxna (främst kriminellt belastade) personer. Checklistan består av 20 element som bedöms med 0-2. Verktyget kräver ett rätt stort informationsunderlag (belastningsregister, rapporter, intervjuer osv från t.ex. polis, domstol och kriminalvård).

\subsubsection{Static-99 resp. Static-2002}

Aktuariska bedömningsinstrument för att skatta risken för återfall i sexuellt våld. Elementen i respektive checklista berör sexualförbrytelser, sexuella avvikelser, förhållande till den hotade personen, samt allmän kriminalitet. Static-2002 är något mer omfattande med 13 element (jämfört med 10 i Static-99). 


\subsubsection{SVR-20 (Sexual Violence Risk-20)}

SVR-20 är ett verktyg för att bedöma risk för återfall i sexuellt våld. Verktyget omfattar 20 riskfaktorer som inordnas under psykosocial anpassning, sexualförbrytelser samt framtidsplaner.

\subsubsection{LS/CMI (Level of Service/Case Management Inventory)}

LS/CMI är ett instrument för att bedöma och hantera risk för återfall i kriminalitet bland äldre tonåringar och vuxna. Används framför allt inom kriminalvård. 
Ved Stranden 18

DK-1061 København K

www.norden.org

\section{Riskbedömning av partnervåld}

Många myndigheter möter våldsutsatta eller våldsutövare och kunde - om de klarade av att identifiera våldet och dess omfattning - vidta åtgärder för att skydda våldsoffren. I denna rapport redogörs för nordiska myndigheters användning och erfarenheter av strukturerade instrument för att bedöma risken för förekomst av våld i partnerrelationer. Riskbedömningsarbetet handlar om att kartlägga risken för våld, uppskatta hur allvarlig den är och vilka följder det eventuella våldet kan få. Utgående från denna bedömning vidtas nödvändiga åtgärder för att minimera risken för att våld brukas. I kartläggningen framgår att myndigheterna använder riskbedömningsinstrumenten i varierande grad men där de används är erfarenheterna gen erellt sett goda. Arbetet förutsätter att det är grundligt förankrat i verksamheten.

Effektivt riskbedömningsarbete betyder förbättrat skydd för våldsutsatta.

TemaNord 2014:521

ISBN 978-92-893-2753-4

ISBN 978-92-893-2754-1 (EPUB)

ISSN 0908-6692

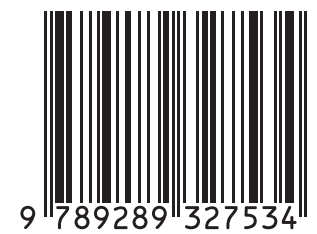

